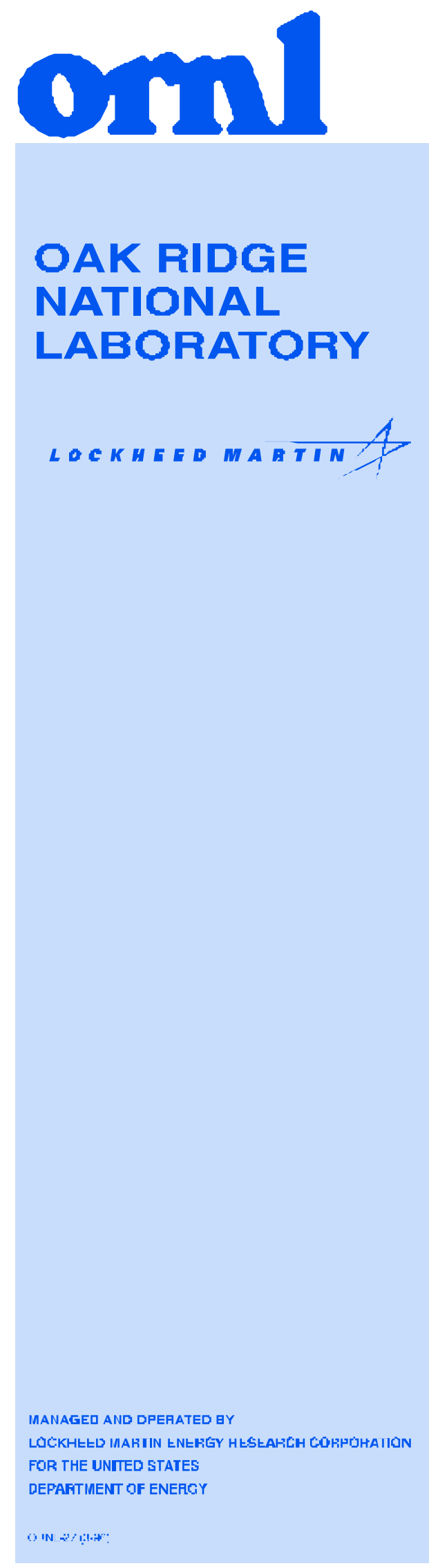

\title{
Shielding and Criticality
Analyses of Phase I Reference
Truck and Rail Cask Designs for \\ Shielding and Criticality
Analyses of Phase I Reference
Truck and Rail Cask Designs for \\ Shielding and Criticality
Analyses of Phase I Reference
Truck and Rail Cask Designs for Spent Nuclear Fuel
}

\author{
B. L. Broadhead \\ R. L. Childs \\ C. V. Parks
}


This report has been reproduced directly from the best available copy.

Available to DOE and DOE contractors from the Office of Scientific and Technical Information, P.O. Box 62, Oak Ridge, TN 37831; prices available from (615) 576-8401.

Available to the public from the National Technical Information Service, U.S. Department of Commerce, 5285 Port Royal Rd., Springfield, VA 22161.

This report was prepared as an account of work sponsored by an agency of the United States Government. Neither the United States nor any agency thereof, nor any of their employees, makes any warranty, express or implied, or assumes any legal liability or responsibility for the accuracy, completeness, or usefulness of any information, apparatus, product, or process disclosed, or represents that its use would not infringe privately owned rights. Reference herein to anyspecific commercial product, process, or service by trade name, trademark, manufacturer, or otherwise, does not necessarily constitute or imply its endorsement, recommendation, or favoring by the United States Government or any agency thereof. The views and opinions of authors expressed herein do not necessarily state or reflect those of the United States Government or any agency thereof. 
ORNL/TM-12395

Limited Distribution

Computational Physics and Engineering Division

\title{
SHIELDING AND CRITICALITY ANALYSES OF PHASE I REFERENCE TRUCK AND RAIL CASK DESIGNS FOR SPENT NUCLEAR FUEL
}

\author{
B. L. Broadhead \\ R. L. Childs \\ C. V. Parks
}

Date Prepared: October 1992

Date Published: March 1996

Work Performed for the

DOE Office of Civilian Radioactive Waste Management

Under Memorandum Purchase Order DX4712BT2X With

TRW Environmental Safety Systems, Inc.

\author{
Prepared by the \\ OAK RIDGE NATIONAL LABORATORY \\ managed by \\ LOCKHEED MARTIN ENERGY RESEARCH CORP. \\ for the \\ U.S. DEPARTMENT OF ENERGY \\ under contract DE-AC05-96OR22464
}





\section{CONTENTS}

Page

LIST OF FIGURES $\ldots \ldots \ldots \ldots \ldots \ldots \ldots \ldots \ldots \ldots \ldots \ldots \ldots \ldots \ldots \ldots \ldots$

LIST OF TABLES $\ldots \ldots \ldots \ldots \ldots \ldots \ldots \ldots \ldots \ldots \ldots \ldots \ldots \ldots \ldots \ldots \ldots \ldots$

PREFACE $\ldots \ldots \ldots \ldots \ldots \ldots \ldots \ldots \ldots \ldots \ldots \ldots \ldots \ldots \ldots \ldots \ldots \ldots$ vii

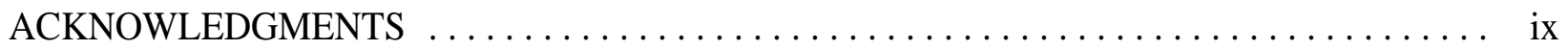

ABSTRACT $\ldots \ldots \ldots \ldots \ldots \ldots \ldots \ldots \ldots \ldots \ldots \ldots \ldots \ldots \ldots \ldots \ldots \ldots \ldots \ldots$

1. INTRODUCTION $\ldots \ldots \ldots \ldots \ldots \ldots \ldots \ldots \ldots \ldots \ldots \ldots \ldots \ldots \ldots \ldots$

2. ONE-DIMENSIONAL SHIELDING CALCULATIONS $\ldots \ldots \ldots \ldots \ldots \ldots \ldots \ldots \ldots \ldots 2$

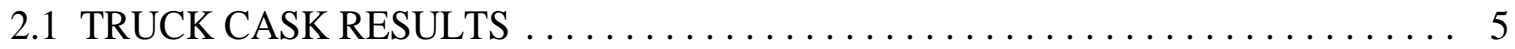

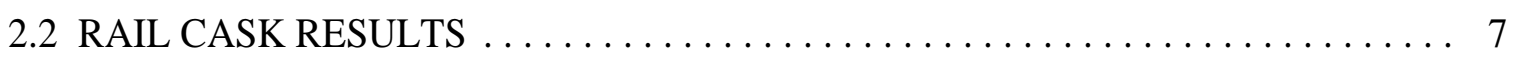

3. TWO-DIMENSIONAL CALCULATIONS $\ldots \ldots \ldots \ldots \ldots \ldots \ldots \ldots \ldots \ldots \ldots \ldots$

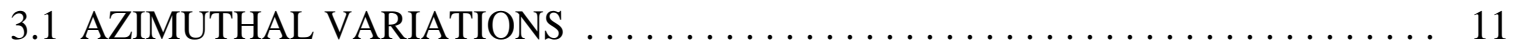

3.2 AXIAL VARIATIONS $\ldots \ldots \ldots \ldots \ldots \ldots \ldots \ldots \ldots \ldots \ldots \ldots \ldots \ldots \ldots$

4. CRITICALITY CALCULATIONS $\ldots \ldots \ldots \ldots \ldots \ldots \ldots \ldots \ldots \ldots \ldots \ldots \ldots \ldots \ldots \ldots \ldots \ldots \ldots, 26$

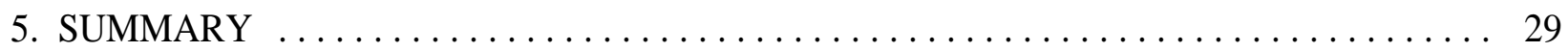

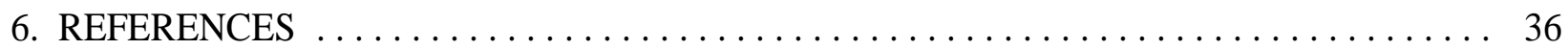




\section{LIST OF FIGURES}

$\underline{\text { Figure }}$

Page

1. R-2 DORT model for 2 -assembly DU truck cask $\ldots \ldots \ldots \ldots \ldots \ldots \ldots \ldots \ldots \ldots \ldots$

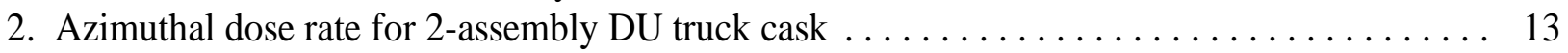

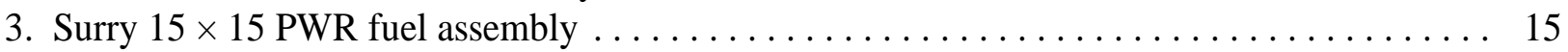

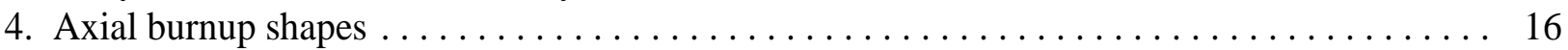

5. Two-dimensional dose rates $(\mathrm{mrem} / \mathrm{h})$ for $2 \mathrm{PWR}$ assembly depleted uranium

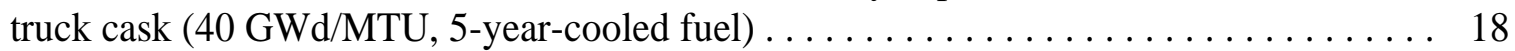

6. Two-dimensional dose rates (mrem/h) for $12 \mathrm{PWR}$ assembly depleted uranium rail cask $(40 \mathrm{GWd} / \mathrm{MTU}, 5$-year-cooled fuel) . . . . . . . . . . . . . . . . . . . . . . 19

7. Truck cask surface dose rates $\ldots \ldots \ldots \ldots \ldots \ldots \ldots \ldots \ldots \ldots \ldots \ldots \ldots \ldots \ldots$

8. Truck cask dose rates at edge of truck bed $\ldots \ldots \ldots \ldots \ldots \ldots \ldots \ldots \ldots \ldots \ldots \ldots \ldots \ldots$

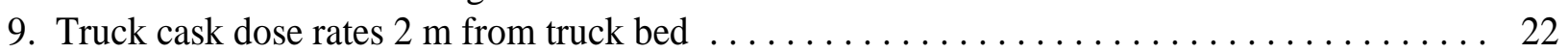

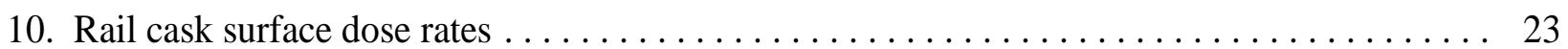

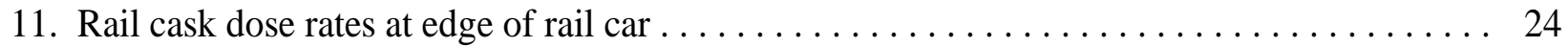

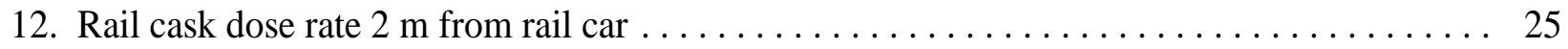

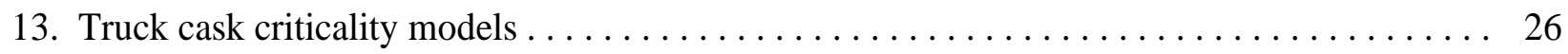

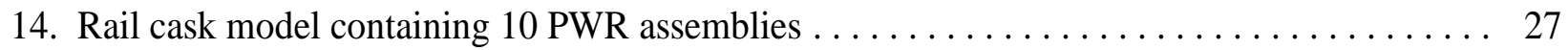

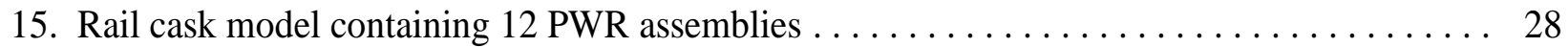

16. Dose rate vs burnup and cooling time for 2 PWR assembly truck casks $\ldots \ldots \ldots \ldots \ldots .30$

17. Dose rate vs burnup and cooling time for 5 BWR assembly truck casks $\ldots \ldots \ldots \ldots \ldots \ldots$

18. Dose rate vs burnup and cooling time for 8 PWR assembly rail casks . . . . . . . . . . . 32

19. Dose rate vs burnup and cooling time for 10 and 12 PWR assembly rail casks . . . . . . 33

20. Dose rate vs burnup and cooling time for 8-10 PWR assemblies in modified rail cask with $\mathrm{Pb}$ shielding $\ldots \ldots \ldots \ldots \ldots \ldots \ldots \ldots \ldots \ldots \ldots \ldots \ldots \ldots \ldots$

21. Dose rate vs burnup and cooling time for 10-12 assemblies in modified rail cask with depleted uranium shielding $\ldots \ldots \ldots \ldots \ldots \ldots \ldots \ldots \ldots \ldots \ldots \ldots \ldots \ldots \ldots \ldots \ldots \ldots$ 


\section{LIST OF TABLES}

\section{$\underline{\text { Table }}$}

$\underline{\text { Page }}$

1. One-dimensional cylindrical models for reference truck cask $\ldots \ldots \ldots \ldots \ldots \ldots \ldots \ldots \ldots$

2. One-dimensional cylindrical models for reference rail cask $\ldots \ldots \ldots \ldots \ldots \ldots \ldots \ldots \ldots$

3. One-dimensional cylindrical models for modified rail cask $\ldots \ldots \ldots \ldots \ldots \ldots \ldots \ldots \ldots \ldots$

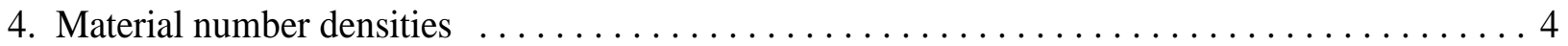

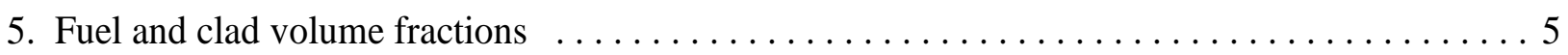

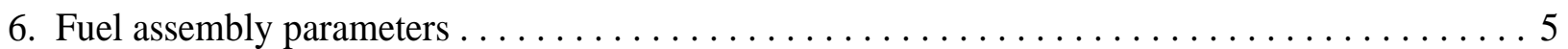

7. One-dimensional dose results $(\mathrm{mrem} / \mathrm{h})$ for TESS truck cask $\ldots \ldots \ldots \ldots \ldots \ldots \ldots$

8. Summary of burnup and initial enrichment combinations for the SNF radiation sources . . . . . 7

9. One-dimensional dose results $(\mathrm{mrem} / \mathrm{h})$ for TESS rail cask $\ldots \ldots \ldots \ldots \ldots \ldots \ldots \ldots$

10. One-dimensional dose results $(\mathrm{mrem} / \mathrm{h})$ for modified TESS rail cask $\ldots \ldots \ldots \ldots \ldots \ldots$

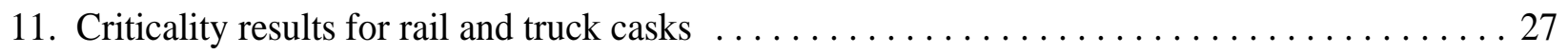





\section{PREFACE}

This work was performed to support planning activities associated with a request for proposals (RFP) to design spent nuclear fuel tranpsortation casks. Subsequent to the completion of these planning activities, the decision was made not to release the RFP. However, this work is being released because it could be useful for future cask design activities. The RFP, designated as Phase I, was to be issued by TRW Environmental Safety Systems at the request of the DOE Office of Civilian Radioactive Waste Management. 



\section{ACKNOWLEDGMENTS}

The authors wish to acknowledge D. J. Nolan of TRW Environmental Safety Systems (TESS) for his support and assistance in funding this work. Appreciation is also expressed to J. C. Turner for his preparation of the figures used in this report and to L. Norris for her careful preparation of the manuscript. The review of this document by J. S. Tang and M. D. DeHart is also acknowledged.

This work was performed under the sponsorship of TESS, which serves as a management and operating contractor for the U.S. Department of Energy (DOE) Office of Civilian Radioactive Waste Management (OCRWM) program. 



\begin{abstract}
This work was performed in support of the planned Phase I request for proposals (RFP) for spent nuclear fuel (SNF) transportation cask designs. The funding for this work was provided by the Office of Civilian Radioactive Waste Management (OCRWM) through its M\&O contractor, TRW Environmental Safety Systems (TESS). The objective of this work was to prepare for the criticality and shielding evaluation of the Phase I cask design proposals by investigating the effect of SNF and design variables on reference cask models. Prior knowledge in this area should mitigate the analysis effort required for the bid evaluation process. The effect of SNF burnup/age characteristics on payload, the effect of initial enrichment on the radiation source and dose, and the relative effectiveness of several gamma-ray and neutron shield materials were all areas of investigation. In addition, the results of this effort provide data that can be used to assess the practicality of the RFP specifications regarding the targeted performance of the Phase I casks. Although the final RFP for the Phase I cask was never issued, this report has been issued because of its potential value in future SNF cask design efforts.

Results are presented herein to determine the adequacy with respect to shielding regulations of reference designs for a truck cask containing 2 PWR or 5 BWR assemblies of standard burnup (45 GWd/MTU for PWR, $40 \mathrm{GWd} / \mathrm{MTU}$ for BWR) and 1 PWR assembly with extended burnup (55 GWd/MTU). The study also includes reference and modified rail cask designs with projected payloads of 8,10 , or 12 PWR assemblies. The burnup/age trends are analyzed in one dimension for both $\mathrm{Pb}$ and depleted uranium (DU) gamma-ray shields. The two-dimensional analyses concentrate on multidimensional aspects of each design and the degree to which the onedimensional results are adequate. Both cask types are also analyzed for adequacy from a criticality safety standpoint.

The results of the two-dimensional shielding analysis uphold the one-dimensional results as being an appropriate means of studying the burnup/age trends for the truck cask. These results show that the reference design for the $\mathrm{Pb}$-shield truck cask is inadequate for all cases considered, while the DU-shield truck cask is capable of carrying the desired payloads. The one-dimensional shielding analysis results for the reference $\mathrm{Pb}$ and $\mathrm{DU}$ rail casks indicate substantial margins exist in the side doses for reasonable burnup/age combinations. For a Pb-cask configuration, margins exist primarily for long-cooled (15 years) fuel. For the modified $\mathrm{Pb}$ and $\mathrm{DU}$ rail casks, the $2-\mathrm{m}$ dose rates offer substantial margins below the regulatory limits for all burnup values considered provided the spent fuel has cooled for $\$ 10$ years. The modified $\mathrm{Pb}$ and $\mathrm{DU}$ casks yield essentially identical results and, hence, could be considered equivalent from a shielding perspective.

The criticality analyses that were performed indicate that a truck basket can be designed to provide an adequate subcritical margin for $2 \mathrm{PWR}$ assemblies enriched to $5 \mathrm{wt} \%$. While the 10 - and 12 -assembly rail cask designs are very close to the regulatory limit of 0.95 for $_{\mathrm{eff}}$, after accounting for a 0.01 ) $\mathrm{k}$ bias and 2 standard deviations, the limit is exceeded by about $3 \%$. It is believed that a combination of decreased enrichments and/or increased water gaps should allow these baskets to be acceptable.
\end{abstract}





\section{INTRODUCTION}

This report summarizes the criticality and shielding analyses performed in support of the planned Phase I request for proposals (RFP) for spent nuclear fuel (SNF) transportation cask designs. This work was sponsored by the Office of Civilian Radioactive Waste Management (OCRWM) through its M\&O contractor, TRW Environmental Safety Systems (TESS). The objective of this work was to prepare for the criticality and shielding evaluation of the Phase I cask design proposals by investigating the effect of SNF and design variables on reference cask models. Prior knowledge in this area should mitigate the analysis effort required for the bid evaluation process. The effect of SNF burnup/age characteristics on payload, the effect of initial enrichment on the radiation source and dose, and the relative effectiveness of several gamma-ray and neutron shield materials were all areas of investigation. In addition, the results of this effort provide data that can be used to assess the practicality of the RFP specifications regarding the targeted performance of the Phase I casks. Although the final RFP for the Phase I cask was never issued, this report has been issued because of its potential value in future SNF cask design efforts.

The nature of the design process of a SNF transportation cask involves the interplay of a large number of variables. The primary variables influencing the criticality evaluation are the initial ${ }^{235} \mathrm{U}$ enrichment, the thickness/arrangement of basket poison materials, and, to a lesser extent, the shield composition and thickness. These effects are usually evaluated via a three-dimensional (3-D) model using maximum enrichments and a typical basket material/configuration. For shielding evaluations, the primary variables include the fuel age/burnup, the composition and thickness of the basket material, the composition and thickness of the neutron and gamma-ray shields, and, to a lesser extent, the initial ${ }^{235} \mathrm{U}$ enrichment. For shielding studies, a large number of cases must be evaluated to cover the full range of parameters. The procedure used in this study was to perform many of these evaluations with a one-dimensional (1-D) discrete ordinates technique, while several twodimensional (2-D) discrete-ordinates cases were used to augment the 1-D predictions. The adequacy of the computer codes used to obtain the shielding and criticality results are discussed in refs. 1-5. All dose results presented in this report were assessed against the dose requirements of 10CFR71 (ref. 6) for exclusive-use packages (i.e., $200 \mathrm{mrem} / \mathrm{h}$ cask surface and $10 \mathrm{mrem} / \mathrm{h}$ at $2 \mathrm{~m}$ from the vehicle edge).

The next section describes the results of the 1-D discrete ordinates analyses, followed by the 2-D shielding analysis results in the subsequent section. The final sections give the criticality results and incorporate all the analysis results into the development of final conclusions. 


\section{ONE-DIMENSIONAL SHIELDING CALCULATIONS}

A series of 1-D scoping calculations was performed for several conceptual truck and rail cask designs specified by TESS. These results are valuable for evaluating effects for a large number of design variables. One-dimensional calculational methods were utilized to allow for characterization of a large number of design variables in a quick and efficient manner. Inaccuracies resulting from the limitations of a 1-D model were assessed using a limited number of 2-D analysis models. The results for the 2-D analyses are provided in the next section of this report.

These 1-D calculations were performed using the SCALE system 7 module SAS1. The SAS1 module automates the analysis sequence that executes the cross-section processing modules, BONAMI and NITAWL-II, prior to execution of XSDRNPM-S (1-D discrete ordinates code) to obtain the angular leakage from the exterior of the cylindrical cask. The module XSDOSE is accessed to estimate the flux and dose rate at detectors external to the cask shield body. XSDOSE then reports the dose rates at both the cask surface and the 2-m location (2 $\mathrm{m}$ from the 240.6-cm-wide truck bed or 300.8-cm-wide rail car). The cross sections used in this study are from the SCALE 27-neutron/18-gamma-group library, which includes a set of flux-to-dose conversion factors based on ANSI/ANS-6.1.1-1977. ${ }^{8}$ This library allows the inclusion of neutron, primary-gamma, and secondarygamma contributions to the dose.

One-dimensional models were developed in cylindrical geometry to analyze the reference and modified cask configurations as specified by TESS. These models are given in Table 1 for the reference truck cask, Table 2 for the reference rail cask, and Table 3 for the modified rail cask. Separate specifications are given for both lead $(\mathrm{Pb})$ and depleted uranium (DU) cask body configurations. These $\mathrm{Pb}$ and $\mathrm{DU}$ cask models allow the relative merits of the two shield materials to be evaluated.

The material number densities for the various materials given in Tables 1 through 3 are presented in Table 4. The number densities for the SS-304, lead, and depleted U were taken from the SCALE Standard Composition Library. The number densities of the borated polyethylene and borated ethylene glycol (BEG) were taken from the Safety Analysis Report for Package: ${ }^{9,10}$ written for the GA-4/9 and the NAC-LWT casks, respectively. The number densities shown in the table are based on a $\mathrm{UO}_{2}$ density of $10.96 \mathrm{~g} / \mathrm{cc}$ and a ${ }^{235} \mathrm{U}$ enrichment of $3.72 \mathrm{wt} \%$. The enrichment variations were included in the radiation source-term determination (see Sect. 2.1), where they can be important. The enrichment (fixed at $3.72 \mathrm{wt} \%$ ) was not varied in the transport portion of the shielding calculations because previous experience has shown it is not important. The densities are given as full-density fuel and Zircaloy. The volume fraction modifiers in Table 5 were used to homogeneously smear the fuel and clad over the entire cask cavity area. Any remaining materials in the cavity (i.e., basket webs, assembly cans, basket formers, etc.) were not included in the cavity region to assure conservative results. Additionally, homogenization of the fuel spreads the source particles uniformly over the cask cavity area and should also increase the calculated dose at the detector.

The fuel-assembly parameters assumed for the Pressurized-Water Reactor (PWR) and Boiling-Water Reactor (BWR) fuel are given in Table 6. These parameters were used to determine the fuel and clad volume fractions given in Table 5. The total neutron and gamma-ray sources input to the calculations were obtained using the MTU/assembly values in Table 6 and the data base of source particles per MTU that was derived from the Characteristics Data Bas $e^{11}$ and included in the RFP. 
Table 1. One-dimensional cylindrical models for reference truck cask

\begin{tabular}{|c|c|c|c|}
\hline \multicolumn{2}{|c|}{$\mathrm{Pb}$ shield } & \multicolumn{2}{|c|}{ DU shield } \\
\hline Thickness $(\mathrm{cm})$ & Material & Thickness $(\mathrm{cm})$ & Material \\
\hline 27.305 & Smeared fuel ${ }^{\mathrm{a}}$ & 27.305 & Smeared fuel $^{\mathrm{a}}$ \\
\hline 1.905 & SS-304 & 1.270 & SS-304 \\
\hline 7.620 & $\mathrm{~Pb}$ & 6.350 & DU \\
\hline 5.080 & SS-304 & 3.810 & SS-304 \\
\hline 11.430 & Borated polyethylene & 10.160 & Borated polyethylene \\
\hline 0.635 & SS-304 & 0.635 & SS-304 \\
\hline
\end{tabular}

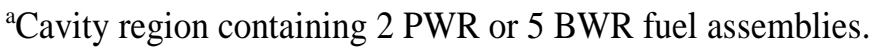

Table 2. One-dimensional cylindrical models for reference rail cask

\begin{tabular}{|c|c|c|c|}
\hline \multicolumn{2}{|c|}{$\mathrm{Pb}$ shield } & \multicolumn{2}{|c|}{ DU shield } \\
\hline Thickness $(\mathrm{cm})$ & Material & Thickness $(\mathrm{cm})$ & Material \\
\hline 55.880 & Smeared fuel $^{\mathrm{a}}$ & 55.880 & Smeared fuel ${ }^{\mathrm{a}}$ \\
\hline 1.905 & SS-304 & 1.905 & SS-304 \\
\hline 11.430 & $\mathrm{~Pb}$ & 7.772 & DU \\
\hline 4.445 & SS-304 & 4.445 & SS-304 \\
\hline 11.430 & Borated polyethylene & 11.430 & Borated polyethylene \\
\hline 1.270 & SS-304 & 1.270 & SS-304 \\
\hline
\end{tabular}

${ }^{\mathrm{a} C a v i t y}$ region containing 8,10 , or $12 \mathrm{PWR}$ assemblies.

Table 3. One-dimensional cylindrical models for modified rail cask

\begin{tabular}{rl|rl}
\hline \multicolumn{2}{c|}{ Pb shield } & \multicolumn{2}{c}{ DU shield } \\
\hline \multicolumn{1}{c|}{ Thickness $(\mathrm{cm})$} & \multicolumn{1}{c}{ Material } & Thickness $(\mathrm{cm})$ & \multicolumn{1}{c}{ Material } \\
\hline 55.880 & Smeared fuel $^{\mathrm{a}}$ & 55.880 & Smeared fuel \\
2.540 & SS-304 & 1.905 & SS-304 \\
12.700 & Pb & 7.366 & DU \\
5.080 & SS-304 & 3.810 & SS-304 \\
12.700 & Borated polyethylene & 12.700 & Borated polyethylene \\
1.270 & SS-304 & 1.270 & SS-304 \\
\hline
\end{tabular}

${ }^{a}$ Cavity region containing 8,10 , or 12 PWR assemblies. 
4

Table 4. Material number densities

\begin{tabular}{|c|c|c|}
\hline Material & Isotope & $\begin{array}{c}\text { Number density } \\
\text { (atom/b-cm) }\end{array}$ \\
\hline \multirow[t]{4}{*}{ Smeared fuel } & ${ }^{235} \mathrm{U}$ & $9.20809 \mathrm{E}-4^{\mathrm{a}}$ \\
\hline & ${ }^{238} \mathrm{U}$ & $2.35311 \mathrm{E}-2^{\mathrm{a}}$ \\
\hline & $\mathrm{O}$ & $4.89037 \mathrm{E}-2^{\mathrm{a}}$ \\
\hline & Zircaloy & $4.25156 \mathrm{E}-2^{\mathrm{a}}$ \\
\hline \multirow[t]{4}{*}{ SS-304 } & $\mathrm{Fe}$ & $5.93579 \mathrm{E}-2$ \\
\hline & $\mathrm{Ni}$ & 7.72074E-3 \\
\hline & $\mathrm{Cr}$ & $1.74286 \mathrm{E}-2$ \\
\hline & $\mathrm{Mn}$ & $1.73633 \mathrm{E}-3$ \\
\hline Lead & $\mathrm{Pb}$ & $3.29864 \mathrm{E}-2$ \\
\hline \multirow[t]{5}{*}{ Borated polyethylene } & $\mathrm{O}$ & $1.50446 \mathrm{E}-3$ \\
\hline & $\mathrm{H}$ & 7.43774E-2 \\
\hline & ${ }^{10} \mathrm{~B}$ & $1.00139 \mathrm{E}-4$ \\
\hline & ${ }^{11} \mathrm{~B}$ & 4.01217E-4 \\
\hline & $\mathrm{C}$ & $3.64625 \mathrm{E}-2$ \\
\hline \multirow[t]{2}{*}{ Depleted U } & ${ }^{238} \mathrm{U}$ & 4.80957E-2 \\
\hline & ${ }^{235} \mathrm{U}$ & $9.76171 \mathrm{E}-5$ \\
\hline \multirow{4}{*}{$\begin{array}{l}\text { Borated ethylene } \\
\text { glycol (BEG) }\end{array}$} & $\mathrm{O}$ & $3.15000 \mathrm{E}-2$ \\
\hline & $\mathrm{H}$ & $5.73000 \mathrm{E}-2$ \\
\hline & ${ }^{10} \mathrm{~B}$ & $2.02541 \mathrm{E}-5$ \\
\hline & ${ }^{11} \mathrm{~B}$ & $8.22256 \mathrm{E}-5$ \\
\hline
\end{tabular}

${ }^{a}$ Full-density values; see Table 5 for volume fraction modifiers. 
Table 5. Fuel and clad volume fractions

\begin{tabular}{lcll}
\hline Cask type & $\begin{array}{c}\text { Number of } \\
\text { assemblies }\end{array}$ & $\begin{array}{l}\text { Fuel volume } \\
\text { fraction, } \mathrm{V}_{\mathrm{f}}\end{array}$ & $\begin{array}{l}\text { Clad volume } \\
\text { fraction, } \mathrm{V}_{\mathrm{c}}\end{array}$ \\
\hline Rail & 8 PWR & 0.0979 & 0.0348 \\
Rail & 10 PWR & 0.1223 & 0.0435 \\
Rail & 12 PWR & 0.1468 & 0.0522 \\
& & & \\
Truck & 2 PWR & 0.1024 & 0.0364 \\
Truck & 1 PWR & 0.0623 & 0.0222 \\
Truck & 5 BWR & 0.1102 & 0.0419 \\
\hline
\end{tabular}

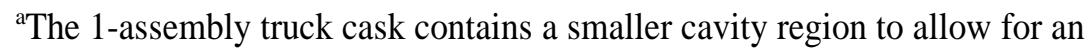
extra $2.54 \mathrm{~cm}$ of shielding material.

Table 6. Fuel assembly parameters ${ }^{\mathrm{a}}$

\begin{tabular}{llll}
\hline \multicolumn{2}{c}{ Combustion Engineering $16 \times 16$ PWR } & \multicolumn{1}{c}{ General Electric $8 \times 8$ BWR } \\
\hline Overall length & $449.6 \mathrm{~cm}$ & Rod pitch & $1.626 \mathrm{~cm}$ \\
Active fuel height & $381 \mathrm{~cm}$ & Fuel rod OD & $1.252 \mathrm{~cm}$ \\
Pin OD & $0.97 \mathrm{~cm}$ & Pellet OD & $1.056 \mathrm{~cm}$ \\
Diametric gap & $0.0178 \mathrm{~cm}$ & Clad ID & $1.08 \mathrm{~cm}$ \\
Clad thickness & $0.064 \mathrm{~cm}$ & Active fuel length & $365.76 \mathrm{~cm}$ \\
Clad material & Zirc-4 & Pellet TD & $95 \%$ \\
Rod length & $409 \mathrm{~cm}$ & No. rods/assembly & 62 \\
Rod pitch & $1.29 \mathrm{~cm}$ & Clad material & Zirc-2 \\
No. rods/assembly & 236 & UO $_{2}$ weight & 0.1825 MTU/assembly \\
Pellet TD & $95 \%$ & & \\
Pellet OD & $0.83 \mathrm{~cm}$ & & \\
UO $_{2}$ weight & $0.442 \mathrm{MTU} /$ assembly & & \\
\hline
\end{tabular}

${ }^{\mathrm{a}}$ From ref. 12.

\subsection{TRUCK CASK RESULTS}

The 1-D results for TESS truck casks are given in Table 7. These results were obtained using the radiation source terms provided in the RFP at the enrichments given in Table 8. For the truck cask results in Table 7, dose rates are presented at various burnup/cooling times for 1 and $2 \mathrm{PWR}$ assemblies in $\mathrm{Pb}$ and DU casks, and for $5 \mathrm{BWR}$ assemblies in both $\mathrm{Pb}$ and DU casks. The 1-PWR-assembly cases have a DU gamma shield with an additional $2.54-\mathrm{cm} \mathrm{Pb}$ shield inside the cavity region. One additional series of calculations presented in Table 7 includes the incorporation of 2.54 and $5.08 \mathrm{~cm}$ of additional $\mathrm{Pb}$ in the shield region for a $\mathrm{Pb}$ cask containing $2 \mathrm{PWR}$ assemblies. 
Table 7. One-dimensional ${ }^{\mathrm{a}}$ dose results $(\mathrm{mrem} / \mathrm{h})$ for TESS truck cask ${ }^{\mathrm{b}}$

\begin{tabular}{|c|c|c|c|c|c|}
\hline Shield material & $\begin{array}{c}\text { No. of } \\
\text { assemblies }\end{array}$ & $\begin{array}{l}\text { Burnup }{ }^{\mathrm{c}} / \\
\text { cooling }\end{array}$ & $\begin{array}{l}\text { Total dose } \\
\text { at surface } \\
\end{array}$ & $\begin{array}{l}\text { Neutron fraction at } \\
2 \mathrm{~m}^{\mathrm{e}} \\
\end{array}$ & $\begin{array}{l}\text { Total dose }{ }^{\mathrm{d}} \text { at } \\
2 \mathrm{~m}(\mathrm{mrem} / \mathrm{h})\end{array}$ \\
\hline DU & 2 PWR & $40 / 5$ & 177.0 & 0.06 & 21.5 \\
\hline DU & 2 PWR & $40 / 10$ & 73.5 & 0.12 & 8.6 \\
\hline DU & 2 PWR & $40 / 15$ & 41.4 & 0.17 & 4.8 \\
\hline DU & 2 PWR & $45 / 5$ & 199.8 & 0.07 & 24.2 \\
\hline DU & 2 PWR & $45 / 10$ & 84.0 & 0.14 & 9.9 \\
\hline DU & 2 PWR & $45 / 15$ & 48.8 & 0.21 & 5.7 \\
\hline DU & 2 PWR & $50 / 5$ & 224.6 & 0.08 & 27.1 \\
\hline DU & 2 PWR & $50 / 10$ & 96.7 & 0.17 & 11.4 \\
\hline DU & 2 PWR & $50 / 15$ & 57.1 & 0.24 & 6.6 \\
\hline $\mathrm{DU}+2.54 \mathrm{~cm} \mathrm{~Pb}$ & 1 PWR & $50 / 5$ & - & 0.17 & 6.5 \\
\hline $\mathrm{DU}+2.54 \mathrm{~cm} \mathrm{~Pb}$ & 1 PWR & $60 / 5$ & - & 0.23 & 8.3 \\
\hline $\mathrm{DU}+2.54 \mathrm{~cm} \mathrm{~Pb}$ & 1 PWR & $60 / 5$ & - & 0.28 & $9.6^{\mathrm{f}}$ \\
\hline $\mathrm{Pb}$ & 2 PWR & $40 / 5$ & 1080.3 & 0.01 & 139.8 \\
\hline $\mathrm{Pb}$ & 2 PWR & $40 / 10$ & 453.1 & 0.02 & 58.3 \\
\hline $\mathrm{Pb}$ & 2 PWR & $40 / 15$ & 246.6 & 0.02 & 31.6 \\
\hline $\mathrm{Pb}$ & 2 PWR & $50 / 5$ & 1344.9 & 0.01 & 173.7 \\
\hline $\mathrm{Pb}$ & 2 PWR & $50 / 10$ & 569.1 & 0.02 & 73.0 \\
\hline $\mathrm{Pb}$ & 2 PWR & $50 / 15$ & 312.0 & 0.04 & 39.9 \\
\hline $\mathrm{Pb}+0 \mathrm{~cm} \mathrm{~Pb}$ & 2 PWR & $45 / 10$ & 510.2 & 0.02 & 65.5 \\
\hline $\mathrm{Pb}+2.54 \mathrm{~cm} \mathrm{~Pb}$ & 2 PWR & $45 / 10$ & 106.1 & 0.08 & 14.4 \\
\hline $\mathrm{Pb}+5.08 \mathrm{~cm} \mathrm{~Pb}$ & 2 PWR & $45 / 10$ & 27.7 & 0.24 & 3.9 \\
\hline DU & $5 \mathrm{BWR}$ & $30 / 5$ & 118.0 & 0.05 & 14.4 \\
\hline DU & $5 \mathrm{BWR}$ & $30 / 10$ & 47.1 & 0.11 & 5.6 \\
\hline DU & $5 \mathrm{BWR}$ & $30 / 15$ & 26.8 & 0.16 & 3.2 \\
\hline DU & $5 \mathrm{BWR}$ & $40 / 5$ & 197.2 & 0.13 & 23.5 \\
\hline DU & $5 \mathrm{BWR}$ & $40 / 10$ & 89.8 & 0.25 & 10.4 \\
\hline DU & $5 \mathrm{BWR}$ & $40 / 15$ & 56.0 & 0.34 & 6.3 \\
\hline DU & $5 \mathrm{BWR}$ & $50 / 5$ & 219.8 & 0.16 & 26.0 \\
\hline DU & $5 \mathrm{BWR}$ & $50 / 10$ & 105.4 & 0.29 & 12.0 \\
\hline DU & $5 \mathrm{BWR}$ & $50 / 15$ & 67.6 & 0.39 & 7.6 \\
\hline $\mathrm{Pb}$ & $5 \mathrm{BWR}$ & $30 / 5$ & 719.2 & 0.01 & 93.1 \\
\hline $\mathrm{Pb}$ & $5 \mathrm{BWR}$ & $30 / 10$ & 299.0 & 0.02 & 38.5 \\
\hline $\mathrm{Pb}$ & $5 \mathrm{BWR}$ & $30 / 15$ & 163.4 & 0.02 & 20.9 \\
\hline $\mathrm{Pb}$ & $5 \mathrm{BWR}$ & $40 / 5$ & 1115.0 & 0.02 & 143.7 \\
\hline $\mathrm{Pb}$ & 5 BWR & $40 / 10$ & 473.2 & 0.04 & 60.5 \\
\hline $\mathrm{Pb}$ & $5 \mathrm{BWR}$ & $40 / 15$ & 263.7 & 0.06 & 33.5 \\
\hline
\end{tabular}

${ }^{a}$ Applicability of 1-D results is discussed in Sects. 3.2 and 5 .

bource terms computed using medium initial enrichment values shown in Table 8, unless otherwise noted.

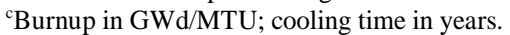

${ }^{\mathrm{d}}$ Includes neutron and both primary- and secondary-gamma contributions. Typically, secondary-gamma contributions are a factor of 5-10 smaller than the neutron contributions.

e $2-\mathrm{m}$ doses are $2 \mathrm{~m}$ from the vehicle edge.

${ }^{\mathrm{f}}$ Source term computed using low initial enrichment value of Table 8. 
Table 8. Summary of burnup and initial enrichment combinations for the SNF radiation sources

\begin{tabular}{|c|c|c|c|c|c|c|}
\hline \multirow{2}{*}{$\begin{array}{c}\text { Burnup } \\
\text { (GWd/MTU) }\end{array}$} & \multicolumn{3}{|c|}{$\begin{array}{c}\text { BWR SNF } \\
\text { Initial enrichment, wt } \%{ }^{235} \mathrm{U}\end{array}$} & \multicolumn{3}{|c|}{$\begin{array}{c}\text { PWR SNF } \\
\text { Initial enrichment, wt } \%{ }^{235} \mathrm{U}\end{array}$} \\
\hline & Low & Medium & High & Low & Medium & High \\
\hline 22.5 & 1.72 & 2.42 & 3.12 & - & - & - \\
\hline 30 & - & 2.93 & - & 2.41 & 3.11 & 3.81 \\
\hline 40 & - & 3.44 & - & - & 3.72 & - \\
\hline 45 & 2.89 & 3.59 & 4.29 & 3.29 & 3.99 & 4.69 \\
\hline 50 & 3.04 & 3.74 & 4.44 & - & 4.26 & - \\
\hline 55 & - & - & - & 3.80 & 4.50 & 5.20 \\
\hline 60 & - & - & - & 4.03 & 4.73 & 5.43 \\
\hline
\end{tabular}

The 1-D results given in Table 7 do not include a number of corrections that will be addressed in the next section via a series of 2-D calculations. These effects include the incorporation of an axial burnup profile and the dose contribution caused by endfittings and groundscatter. These 1-D results are also applicable only on the side of the cask at the axial midplane. Nevertheless, these results are still useful in making preliminary assessments of the feasibility of these conceptual cask concepts.

Based on the 1-D results in Table 7, the DU cask should be capable of carrying 2 PWR assemblies burned to $45 \mathrm{GWd} / \mathrm{MTU}$ with a minimum cooling time somewhere between 10 and 15 years. The same DU cask (with 2.54-cm Pb shielding in the cavity) should meet the regulatory dose rate requirements with a payload of 1 high burnup assembly (55 GWd/MTU and 5-year cooled). The standard Pb cask design as given in Table 1 needs 2.54 to 5.08 additional centimeters of $\mathrm{Pb}$ to carry fuel burned to $45 \mathrm{GWd} / \mathrm{MTU}$ and cooled 10 years.

For BWR fuel, the DU cask should carry 5 BWR assemblies burned to $40 \mathrm{GWd} / \mathrm{MTU}$ and cooled somewhere between 10 and 15 years, while it is estimated that the $\mathrm{Pb}$ cask would need an additional 2.54 to 5.08 $\mathrm{cm}$ of $\mathrm{Pb}$ shielding to carry similar fuel.

\subsection{RAIL CASK RESULTS}

The 1-D results for the reference and modified TESS rail casks are given in Tables 9 and 10 , respectively. These results were also obtained using the radiation source terms provided in the RFP at the medium enrichments given in Table 8. Results are given at various burnup/age combinations for 8,10 , and 12 PWR assemblies in a DU rail cask; and 8 and 10 PWR assemblies in a Pb rail cask. Additional calculations were performed for a $\mathrm{Pb}$ rail cask with $10 \mathrm{PWR}$ assemblies and a variable amount of extra $\mathrm{Pb}$ shielding. No BWR results were generated for the rail cask since the truck cask results showed similar trends for both PWR and BWR assemblies. These results again do not include a number of 2-D effects as stated previously for the truck cask, but should be useful in establishing projected payloads that will meet the regulatory requirements with respect to dose rate limits.

Based on the results in Table 9, the TESS reference rail cask with a DU gamma shield can carry practically any combination of spent fuel assemblies considered. The dose rates for 8,10 , and 12 PWR assemblies burned to $50 \mathrm{GWd} / \mathrm{MTU}$ and cooled for 5 years are the only marginal values for the DU cask. Extrapolation of these 1-D results also indicates that 12 PWR assemblies at $55 \mathrm{GWd} / \mathrm{MTU}$ and 10 years 
8

Table 9. One-dimensional ${ }^{\mathrm{a}}$ dose results $(\mathrm{mrem} / \mathrm{h})$ for TESS rail cask ${ }^{\mathrm{b}}$

\begin{tabular}{|c|c|c|c|c|c|}
\hline Shield material & $\begin{array}{c}\text { No. } \\
\text { assemblies }\end{array}$ & $\begin{array}{l}\text { Burnup } / \\
\text { cooling }\end{array}$ & $\begin{array}{r}\text { Total dose } \\
\text { at surface } \\
\end{array}$ & $\begin{array}{c}\text { Neutron fraction } \\
\text { at } 2 \mathrm{~m}^{\mathrm{d}}\end{array}$ & $\begin{array}{c}\text { Total dose } \\
\text { at } 2 \mathrm{~m}^{\mathrm{d}}\end{array}$ \\
\hline DU & 8 & $40 / 5$ & 34.2 & 0.25 & 5.6 \\
\hline DU & 8 & $40 / 10$ & 17.8 & 0.43 & 2.8 \\
\hline DU & 8 & $40 / 15$ & 12.5 & 0.53 & 1.9 \\
\hline DU & 8 & $45 / 5$ & 43.7 & 0.28 & 7.1 \\
\hline DU & 8 & $45 / 10$ & 23.7 & 0.45 & 3.6 \\
\hline DU & 8 & $45 / 15$ & 16.9 & 0.54 & 2.5 \\
\hline DU & 8 & $50 / 5$ & 49.7 & 0.34 & 8.0 \\
\hline DU & 8 & $50 / 10$ & 28.7 & 0.51 & 4.3 \\
\hline DU & 8 & $50 / 15$ & 21.0 & 0.59 & 3.2 \\
\hline DU & 10 & $40 / 5$ & 36.3 & 0.28 & 5.8 \\
\hline DU & 10 & $40 / 10$ & 19.4 & 0.47 & 3.0 \\
\hline DU & 10 & $40 / 15$ & 13.9 & 0.55 & 2.0 \\
\hline DU & 10 & $45 / 5$ & 44.2 & 0.32 & 7.1 \\
\hline DU & 10 & $45 / 10$ & 25.1 & 0.50 & 3.8 \\
\hline DU & 10 & $45 / 15$ & 18.3 & 0.58 & 2.7 \\
\hline DU & 10 & $50 / 5$ & 53.6 & 0.36 & 8.5 \\
\hline DU & 10 & $50 / 10$ & 31.8 & 0.54 & 4.8 \\
\hline DU & 10 & $50 / 15$ & 23.6 & 0.60 & 3.5 \\
\hline DU & 12 & $40 / 5$ & 40.1 & 0.28 & 6.5 \\
\hline DU & 12 & $40 / 10$ & 21.7 & 0.45 & 3.3 \\
\hline DU & 12 & $40 / 15$ & 15.5 & 0.54 & 2.4 \\
\hline DU & 12 & $45 / 5$ & 48.9 & 0.32 & 7.8 \\
\hline DU & 12 & $45 / 10$ & 27.9 & 0.53 & 4.2 \\
\hline DU & 12 & $45 / 15$ & 20.4 & 0.58 & 3.0 \\
\hline DU & 12 & $50 / 5$ & 59.3 & 0.36 & 9.4 \\
\hline DU & 12 & $50 / 10$ & 35.4 & 0.53 & 5.3 \\
\hline DU & 12 & $50 / 15$ & 26.4 & 0.61 & 3.8 \\
\hline $\mathrm{Pb}$ & 8 & $40 / 5$ & 138.5 & 0.09 & 25.0 \\
\hline $\mathrm{Pb}$ & 8 & $40 / 10$ & 61.1 & 0.18 & 10.7 \\
\hline $\mathrm{Pb}$ & 8 & $40 / 15$ & 36.9 & 0.25 & 6.4 \\
\hline $\mathrm{Pb}$ & 8 & $45 / 5$ & 158.7 & 0.11 & 28.4 \\
\hline $\mathrm{Pb}$ & 8 & $45 / 10$ & 72.5 & 0.21 & 12.6 \\
\hline $\mathrm{Pb}$ & 8 & $45 / 15$ & 44.6 & 0.29 & 7.6 \\
\hline $\mathrm{Pb}$ & 8 & $50 / 5$ & 181.4 & 0.13 & 32.2 \\
\hline $\mathrm{Pb}$ & 8 & $50 / 10$ & 85.3 & 0.24 & 14.7 \\
\hline $\mathrm{Pb}$ & 8 & $50 / 15$ & 53.7 & 0.32 & 9.0 \\
\hline $\mathrm{Pb}+0 \mathrm{~cm} \mathrm{~Pb}$ & 10 & $45 / 10$ & 76.0 & 0.23 & 13.1 \\
\hline $\mathrm{Pb}+2.54 \mathrm{~cm} \mathrm{~Pb}$ & 10 & $45 / 10$ & 32.7 & 0.48 & 5.3 \\
\hline $\mathrm{Pb}+5.08 \mathrm{~cm} \mathrm{~Pb}$ & 10 & $45 / 10$ & 20.5 & 0.66 & 3.3 \\
\hline
\end{tabular}


cooled could be transported with dose values lower than the regulatory limits. For the $\mathrm{Pb}$ rail cask, the standard configuration appears to only support transport of approximately 15 -year-old spent fuel. However, for fuel cooled 15 years, the standard $\mathrm{Pb}$ cask should accommodate approximately 8 assemblies burned to $45 \mathrm{GWd}$ /MTU. With an additional $2.54 \mathrm{~cm}$ of $\mathrm{Pb}$ shielding, the Pb cask should accommodate 10 -year-old spent fuel burned up to $50 \mathrm{GWd} / \mathrm{MTU}$.

A second rail cask, denoted the modified rail cask and described in Table 3, was analyzed for shielding effectiveness over the same set of burnup/age combinations considered for the reference rail cask. These results are shown in Table 10 for a DU cask containing 10 and 12 PWR assemblies and a Pb cask containing 8 and 10 PWR assemblies. As a result of these modifications, the DU and Pb casks are essentially equivalent for shielding purposes. Thus, either cask should be able to transport between 8 and 12 PWR assemblies of any burnup considered provided they have been cooled approximately 9 or 10 years.

Additional calculations were performed to estimate the effect of lower enrichments on the results reported thus far. The use of the low enrichments instead of medium enrichments for the cases evaluated raised the gamma doses by $10 \%$ while the neutron doses increased by about $40 \%$. The overall effect was about $15 \%$ on the total dose. Independent checks of the magnitude of this effect were performed with ORIGEN-S at both 60 and $30 \mathrm{GWd} / \mathrm{MTU}$ burnups and 5-year cooling. Although the individual neutron and gamma-ray effects varied, the $15 \%$ effect on the total dose was seen for both cases. 
10

Table 10. One-dimensional ${ }^{\mathrm{a}}$ dose results $(\mathrm{mrem} / \mathrm{h})$ for modified TESS rail cask ${ }^{\mathrm{b}}$

\begin{tabular}{|c|c|c|c|c|c|}
\hline $\begin{array}{l}\text { Shield } \\
\text { material }\end{array}$ & $\begin{array}{c}\text { No. } \\
\text { assemblies }\end{array}$ & $\begin{array}{c}\text { Burnup } / \\
\text { cooling }\end{array}$ & $\begin{array}{l}\text { Total dose } \\
\text { at surface }\end{array}$ & $\begin{array}{c}\text { Neutron fractions } \\
\text { at } 2 \mathrm{~m}^{\mathrm{d}}\end{array}$ & $\begin{array}{c}\text { Total dose } \\
\text { at } 2 \mathrm{~m}^{\mathrm{d}}\end{array}$ \\
\hline DU & 10 & $40 / 5$ & 52.2 & 0.16 & 8.7 \\
\hline DU & 10 & $40 / 10$ & 24.4 & 0.30 & 3.9 \\
\hline DU & 10 & $40 / 15$ & 16.0 & 0.39 & 2.5 \\
\hline DU & 10 & $45 / 5$ & 61.3 & 0.19 & 10.1 \\
\hline DU & 10 & $45 / 10$ & 30.2 & 0.34 & 4.7 \\
\hline DU & 10 & $45 / 15$ & 20.3 & 0.43 & 3.1 \\
\hline DU & 10 & $50 / 5$ & 71.7 & 0.22 & 11.7 \\
\hline DU & 10 & $50 / 10$ & 37.0 & 0.38 & 5.7 \\
\hline DU & 10 & $50 / 15$ & 25.5 & 0.47 & 3.9 \\
\hline DU & 12 & $40 / 5$ & 57.1 & 0.16 & 9.5 \\
\hline DU & 12 & $40 / 10$ & 27.0 & 0.30 & 4.3 \\
\hline DU & 12 & $40 / 15$ & 17.8 & 0.39 & 2.7 \\
\hline DU & 12 & $45 / 5$ & 67.1 & 0.19 & 11.1 \\
\hline DU & 12 & $45 / 10$ & 33.4 & 0.34 & 5.2 \\
\hline DU & 12 & $45 / 15$ & 22.6 & 0.43 & 3.4 \\
\hline DU & 12 & $50 / 5$ & 78.6 & 0.22 & 12.8 \\
\hline DU & 12 & $50 / 10$ & 40.9 & 0.38 & 6.3 \\
\hline DU & 12 & $50 / 15$ & 28.3 & 0.47 & 4.3 \\
\hline $\mathrm{Pb}$ & 8 & $40 / 5$ & 45.8 & 0.15 & 8.4 \\
\hline $\mathrm{Pb}$ & 8 & $40 / 10$ & 21.9 & 0.27 & 3.9 \\
\hline $\mathrm{Pb}$ & 8 & $40 / 15$ & 14.3 & 0.35 & 2.5 \\
\hline $\mathrm{Pb}$ & 8 & $45 / 5$ & 53.8 & 0.18 & 9.8 \\
\hline $\mathrm{Pb}$ & 8 & $45 / 10$ & 27.0 & 0.30 & 4.7 \\
\hline $\mathrm{Pb}$ & 8 & $45 / 15$ & 18.1 & 0.39 & 3.1 \\
\hline $\mathrm{Pb}$ & 8 & $50 / 5$ & 63.0 & 0.20 & 11.3 \\
\hline $\mathrm{Pb}$ & 8 & $50 / 10$ & 33.0 & 0.34 & 5.7 \\
\hline $\mathrm{Pb}$ & 8 & $50 / 15$ & 22.6 & 0.42 & 3.8 \\
\hline $\mathrm{Pb}$ & 10 & $40 / 5$ & 47.7 & 0.16 & 8.7 \\
\hline $\mathrm{Pb}$ & 10 & $40 / 10$ & 23.5 & 0.29 & 4.1 \\
\hline $\mathrm{Pb}$ & 10 & $40 / 15$ & 15.6 & 0.37 & 2.7 \\
\hline $\mathrm{Pb}$ & 10 & $45 / 5$ & 56.5 & 0.19 & 10.2 \\
\hline $\mathrm{Pb}$ & 10 & $45 / 10$ & 29.2 & 0.33 & 5.0 \\
\hline $\mathrm{Pb}$ & 10 & $45 / 15$ & 19.9 & 0.41 & 3.3 \\
\hline $\mathrm{Pb}$ & 10 & $50 / 5$ & 66.6 & 0.22 & 11.9 \\
\hline \multirow[t]{2}{*}{$\mathrm{Pb}$} & 10 & $50 / 10$ & 35.8 & 0.36 & 6.1 \\
\hline & 10 & $50 / 15$ & 25.0 & 0.44 & 4.2 \\
\hline
\end{tabular}

${ }^{a}$ Applicability of 1-D results is discussed in Sects. 3.2 and 5 .

bource terms computed using medium enrichments.

'Burnup in GWd/MTU, cooling time in years.

d2-m doses are $2 \mathrm{~m}$ from rail car edge. 


\section{TWO-DIMENSIONAL CALCULATIONS}

The 1-D calculations presented in the previous section are useful for scoping calculations and for the evaluation of a large number of design variables, such as shield materials, shield thicknesses, burnup/age trends, etc. Multidimensional calculations are generally required for detailed evaluation of several key areas of a cask design. These areas include the lid and bottom dose rates as well as side dose rates corresponding to the top and bottom endfitting regions. Either 3-D Monte Carlo programs or 2-D discrete ordinates codes are used to evaluate these multidimensional effects. Other multidimensional effects of interest include both azimuthal and axial variations in the predicted dose rate profiles. The azimuthal variations arise from actual geometry variations in the azimuthal direction. The axial dose rate profile variations arise from the nonuniform burnup of fuel in the axial direction, as well as radiation sources present in the endfitting regions. The 3-D Monte Carlo techniques usually handle these variations in a single model, while the 2-D discrete ordinates methods treat the variations independently via $\mathrm{R}-\mathrm{Z}$ calculations for the axial variations and $\mathrm{R}-2$ calculations to evaluate the azimuthal variations. In this study, 2-D discrete ordinates methods were used to study multidimensional effects in both the TESS truck and rail cask loaded with 2 and 12 PWR fuel assemblies, respectively. In both cases, the PWR fuel was assumed to have a burnup of $40 \mathrm{GWd} / \mathrm{MTU}$ with 5 years of cooling time.

\subsection{AZIMUTHAL VARIATIONS}

The estimation of variations in the azimuthal dose was performed by the DORT code 13 using the geometry model shown in Fig. 1. The method involves a three-step procedure: The first step is to obtain, via DORT, the neutron and gamma-ray flux distribution in the cavity in X-Y geometry. The next is to use the X-Y distribution as a source to obtain the neutron and gamma-ray flux distribution in the shield via a DORT R-2 calculation. The final step is to estimate the 2-m flux and dose rates via a modified version of XSDOSE. This modified XSDOSE incorporates the basic formalisms of XSDOSE in that it uses the angular-dependent leakage to estimate the flux and dose external to the shield; however, it allows the DORT R-2 leakage to be utilized.

The material number densities used in the 2-D R-2 analysis were identical to those used in the 1-D analysis with the exception of the fuel and clad volume fractions. The fuel and clad materials were smeared over only the assembly area and not the entire cavity region. The resulting volume fractions were 0.242 for the fuel and 0.082 for the clad.

The surface and 2-m gamma dose rate results are given in Fig. 2, along with the 1-D values obtained previously. The azimuthal variation is about $25 \%$ at the surface and about $12 \%$ at the 2 -m location. However, the 1-D values in both cases are upper bounds on this variation and should therefore be conservative estimates of the actual azimuthal distributions. More importantly, the R-Z models generally use the same radial model as the 1-D calculations; thus the R-Z models can estimate the axial variations while treating the azimuthal variations in a conservative fashion. The results of Fig. 2 also confirm that the minimum dose to the public/workers is obtained when the cask is loaded on the truck with the $0^{\circ}$ axis parallel to the truck bed.

The azimuthal calculations were performed only for the truck cask. Because of the much smaller radial dimensions of the truck cask, the azimuthal variations are expected to be larger for this cask as compared with the rail cask. 


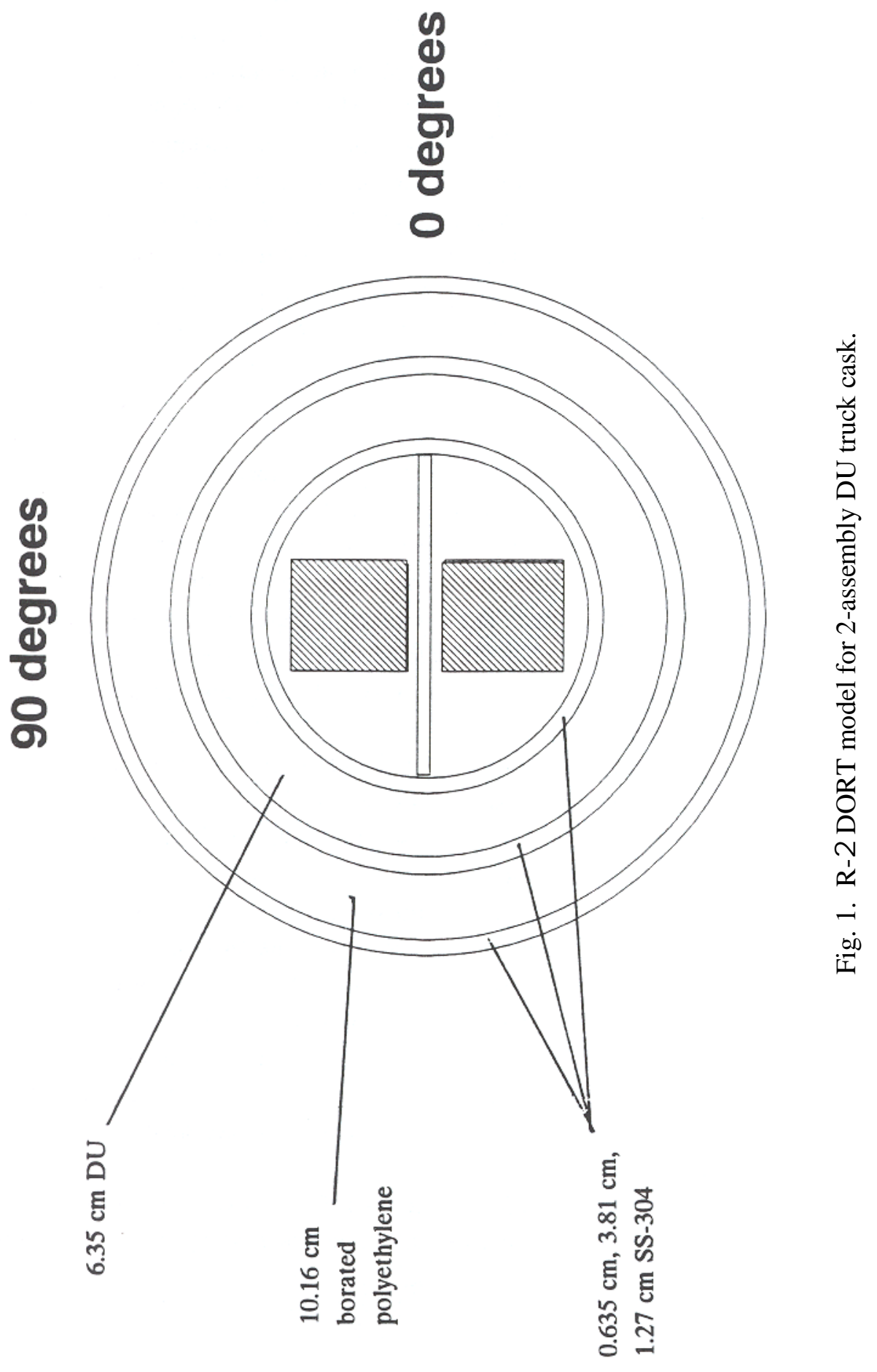




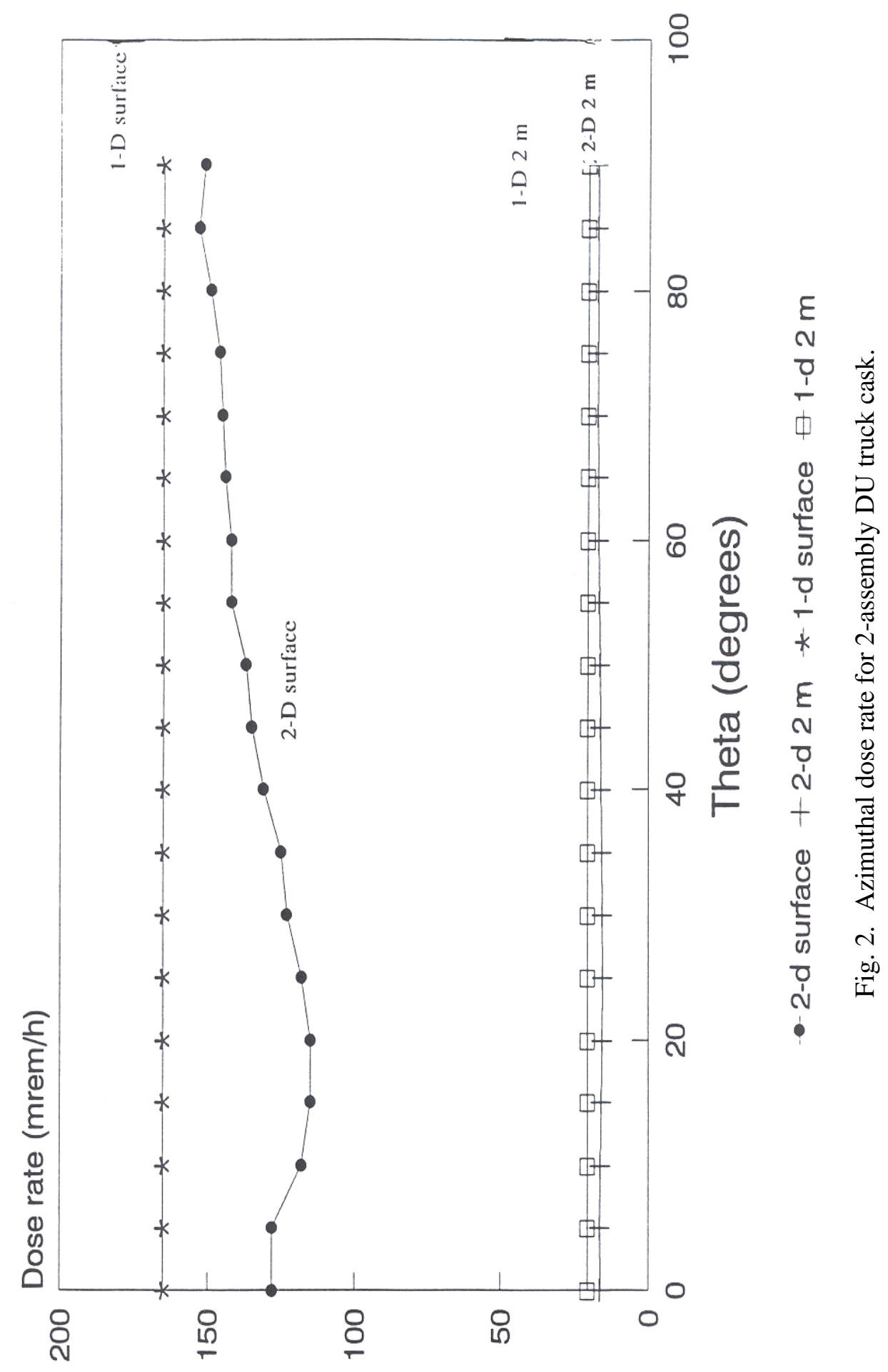




\subsection{AXIAL VARIATIONS}

The evaluation of axial variations in the dose rates incorporates a number of separate effects, including lid and bottom dose rates, varying source distribution due to axial burnup variations, inclusion of endfitting activation sources, and accounting for physical geometry changes from region to region in the axial direction. In two dimensions, these variations are best accounted for in an R-Z calculation.

These R-Z DORT calculations require a very detailed description of the axial regions of the cask. Models for both the truck and rail casks were generated for analysis via the DORT code in R-Z geometry. As a first step, the assemblies must be described completely. This description includes both the assembly geometry and the inherent assembly axial variation of the source. Since a source distribution was not available for the assemblies modeled in the 1-D and R-2 calculations, the assembly type was changed for the R-Z calculations to a Westinghouse $15 \times 15$ PWR assembly for which detailed geometry and source distribution data were available. The shielding characteristics of the Westinghouse assembly are expected to be only negligibly different from the Combustion Engineering $16 \times 16$ PWR assembly previously considered.

Details of the Surry $15 \times 15$ assemblie 3 used in the R-Z calculations are given in Figs. 3 and 4. The axial geometry regions describing the assembly (see Fig. 3) included a bottom nozzle, a gap just above the bottom nozzle, the active fuel, the plenum in the top of each fuel rod, a gap above the fuel rods, and the top nozzle. In each region, the masses of the materials and the total region volumes were utilized to obtain effective smeared densities. The axial burnup peaking factors for typical Surry fuel are shown in Fig. 4. These factors were applied at various axial locations to directly scale the RFP gamma sources, while these factors raised to the fourth power were used to scale the neutron sources contained in the RFP source tables. These scaling factors are applied to the sources obtained using an average burnup and are based on data provided in ref. 11. The fuel sources used in the 2-D analyses correspond to a burnup of $40 \mathrm{GWd} / \mathrm{MTU}$ with 5 years cooling time. The endfitting sources were also taken directly from the RFP (based on data from ref. 11), where ${ }^{60} \mathrm{Co}$ levels are tabulated at burnups of 30 and $60 \mathrm{GWd} / \mathrm{MTU}$. Source values at both 30 and $60 \mathrm{GWd} / \mathrm{MTU}$ were studied for 5-year cooling times in order to assess the sensitivity of the 2-D results to the endfittings. The truck cask analysis used a $60 \mathrm{GWd} / \mathrm{MTU}$ and 5-year-cooled endfitting source, while the rail cask analysis used a 30GWd/MTU and 5-year-cooled endfitting source. The 30-GWd/MTU and 5-year-cooled source was chosen for the rail cask analysis since it is larger than the $60-\mathrm{GWd} / \mathrm{MTU}$ and 10 -year-cooled source and can be scaled up to the $60-\mathrm{GWd} / \mathrm{MTU}$ and 5-year-old source easily. The assemblies with maximum ${ }^{60} \mathrm{Co}$ content were also chosen, CE $16 \times 16$ for the top endfitting and B\&W $15 \times 15$ Mark 4 for the bottom endfittings.

The shielding analyses were performed using the truck and rail cask models shown in Figs. 5 and 6 , respectively. Homogenized fuel assemblies were centered about the axial dimensions of the neutron shield and spanned the entire radius of the cavity. With the exception of the cask bottoms and lids, the axial dimensions of the rail and truck were assumed to be identical with top and bottom impact limiter thicknesses of $57.81 \mathrm{~cm}$ of low density Al, a 24.13-cm SS-304 cask bottom (29.62 cm for the rail cask), an 27.94-cm SS-304 cask lid ( $30.3 \mathrm{~cm}$ for the rail cask), and a cavity height of $457.835 \mathrm{~cm}$. The neutron shield height was $406.4 \mathrm{~cm}$ of either borated polyethylene or BEG as given in Table 4. The DU gamma shield was assumed to span $19.8 \mathrm{~cm}$ above and $15.24 \mathrm{~cm}$ below the cavity. 


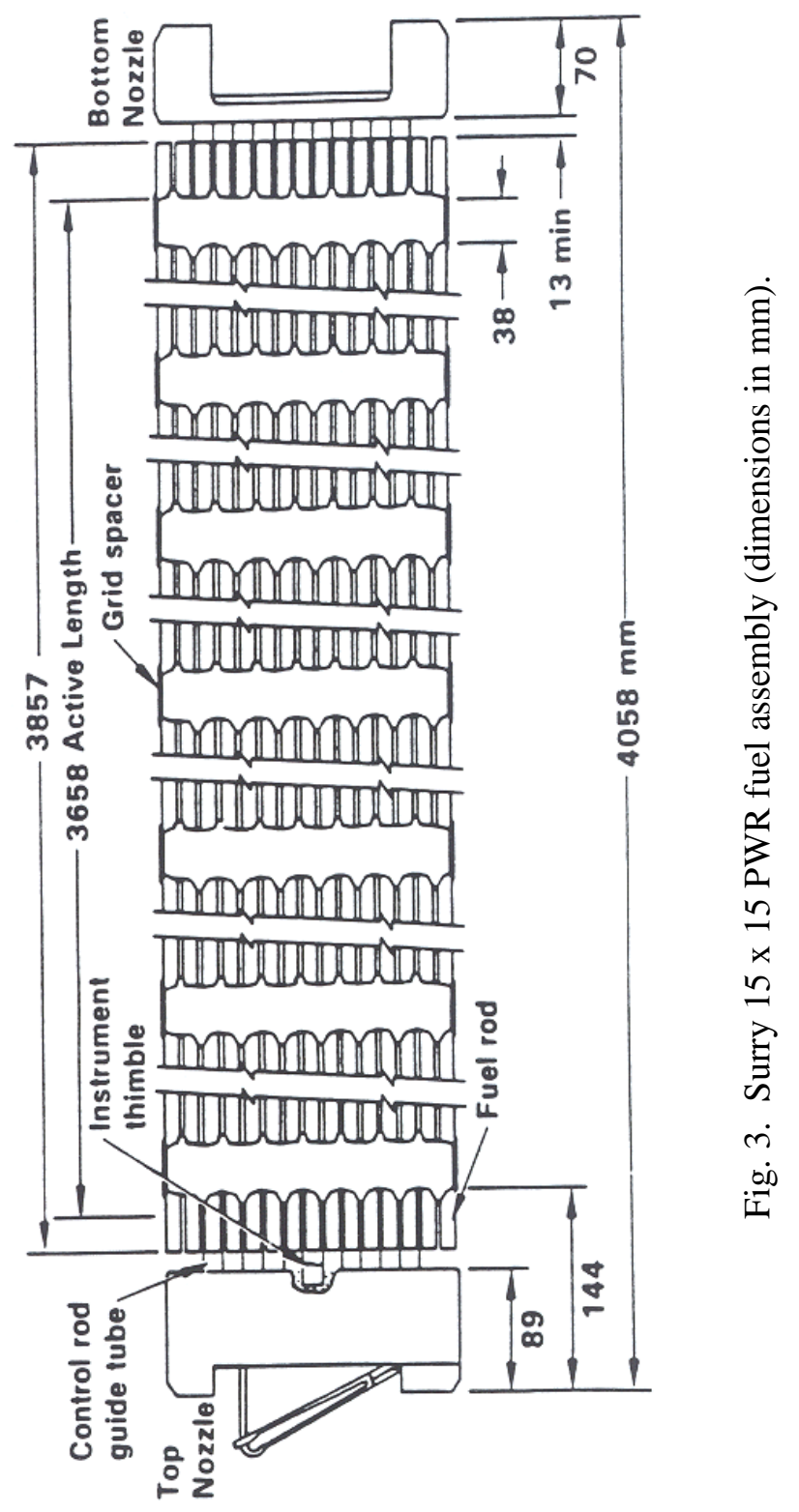




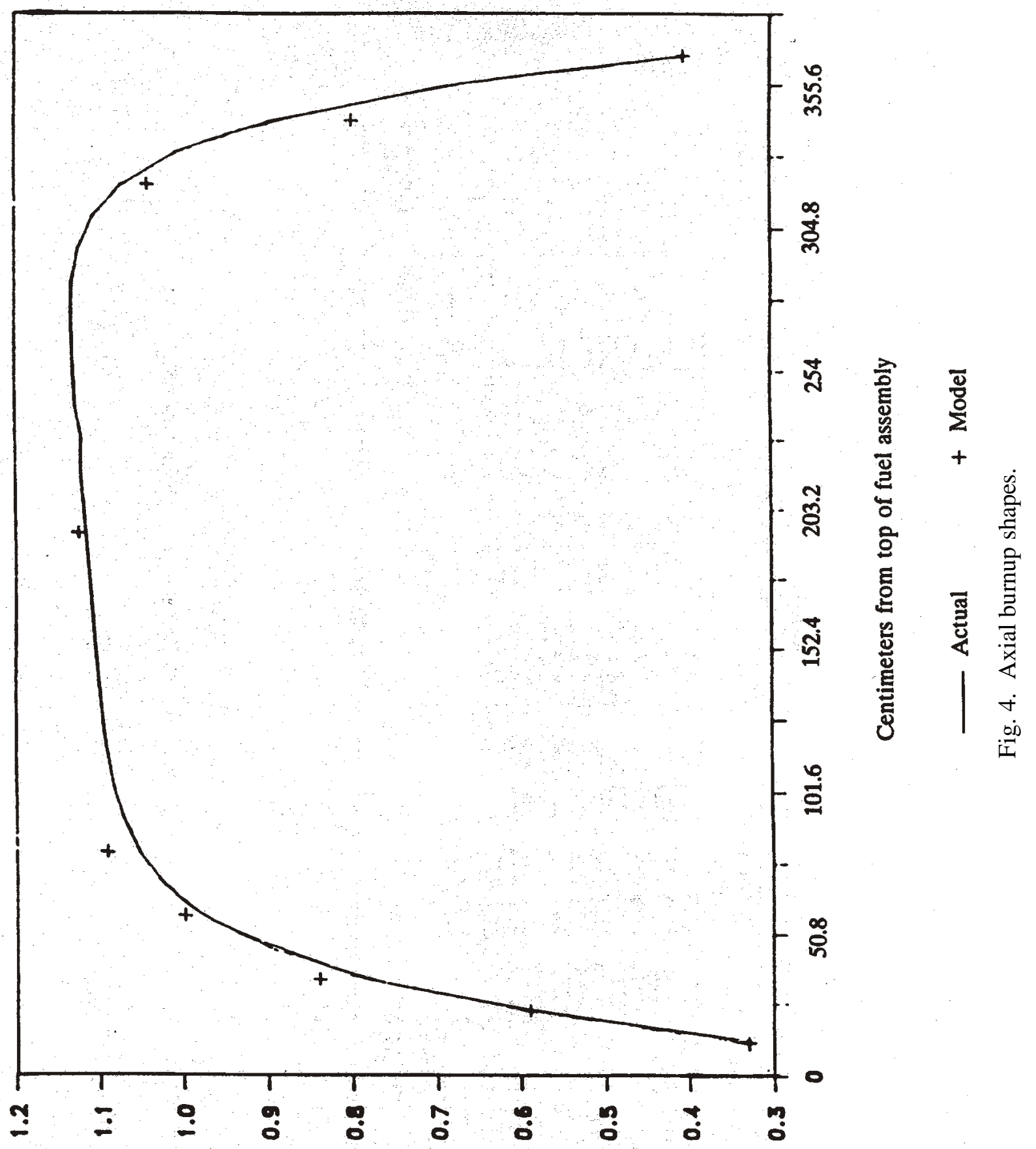

nollsods dnusng 
Calculated dose results are given in Figs. 5 and 6 for selected lid, bottom, and side dose locations for the truck and rail casks, respectively. Neutron and gamma-ray dose rates are presented separately and correspond to peak doses near the top nozzle, ${ }^{*}$ midplane of active fuel, and bottom nozzle ${ }^{*}$ for the cask surface, the edge of the conveyance vehicle (for side doses), and $2 \mathrm{~m}$ from the edge of vehicle (or cask surface for lid and bottom doses). Dose rate profiles are presented ir Figs. 7 through 9 for the truck cask surface, edge of truck bed, and 2-m locations.

The results for the TESS truck cask indicate the peak doses at the 2-m locations occur on the cask side at or near the axial midplane. The peak 2-D result of $22.3 \mathrm{mrem} / \mathrm{h}$ compares very well with the 1-D result of $21.5 \mathrm{mrem} / \mathrm{h}$ shown in Table 7 for $2 \mathrm{PWR}$ assemblies ( $40 \mathrm{GWd} / \mathrm{MTU}, 5$-year-cooled) in a DU cask. Therefore, the 1-D values should represent a good estimate of the 2-m total dose rates. As a result, the 1-D truck cask conclusions should remain unchanged.

The surface dose rates as shown in Fig. 5 indicate that the location of the peak surface doses varies depending upon the assumptions made regarding a personnel barrier. If no such barrier is present, the peak surface dose appears to be along the cask side near the axial midplane $(196.7 \mathrm{mrem} / \mathrm{h})$. If a personnel barrier is placed at or near the vehicle edge, the peak surface dose rate is then along the cask bottom $(133 \mathrm{mrem} / \mathrm{h})$. In neither case is the surface dose the limiting dose rate. Thus, the peak 2-m dose rate along the cask side near the axial midplane should be the limiting shielding design value.

An additional 2-D calculation was performed for the TESS truck cask with the BEG neutron shield material as given in Table 4. The side neutron doses for an identical thickness of BEG were almost uniformly a factor of 1.8 higher than those of the borated polyethylene neutron shield. Since the neutron dose is a small fraction of the total, it appears that use of BEG in the neutron shield would have little effect on the allowable fuel payload characteristics predicted with the 1-D results. A gamma-ray analysis with a BEG neutron shield was not performed, but only a minor effect on the gamma dose is expected.

The 2-D results for the TESS rail cask are shown in Fig. 6. The dose rate profiles for the rail cask are given in Figs. 10 through 12. The general trends discussed above for the truck cask are observed again in the rail cask. The 2-m dose rate along the cask side still peaks near the axial midplane. The peak value of 6.6 $\mathrm{mrem} / \mathrm{h}$ agrees very well with the $1-\mathrm{D}$ result of $6.5 \mathrm{mrem} / \mathrm{h}$. The rail cask surface dose rates are all well below the 200-mrem/h limit. The predicted 2-m dose rate at the cask bottom is some $20 \%$ larger than the peak 2-m side dose rate. However, the 2-m distance is taken to be from the cask bottom. For typical rail car designs, several meters of additional clearance for removal of the impact limiters is included. This additional space on the rail car allows the 2-m dose location to be extended as well and should ensure that the bottom 2-m dose is lower than the side 2-m dose.

For the modified rail cask, the predicted 1-D dose rates along the cask side are indeed higher than these bottom dose rates. Thus, since the top and bottom dose rates should be the same for both the reference and modified rail designs, the side gamma doses should be the limiting quantities for the modified design without the use of an extended bottom dose location.

*The reported surface dose rates at the top and bottom nozzles correspond to the peak doses along the surface with outer radius identical to that of the neutron shield (i.e., $49.53 \mathrm{~cm}$ for the truck cask and $82.7 \mathrm{~cm}$ for the rail cask). 


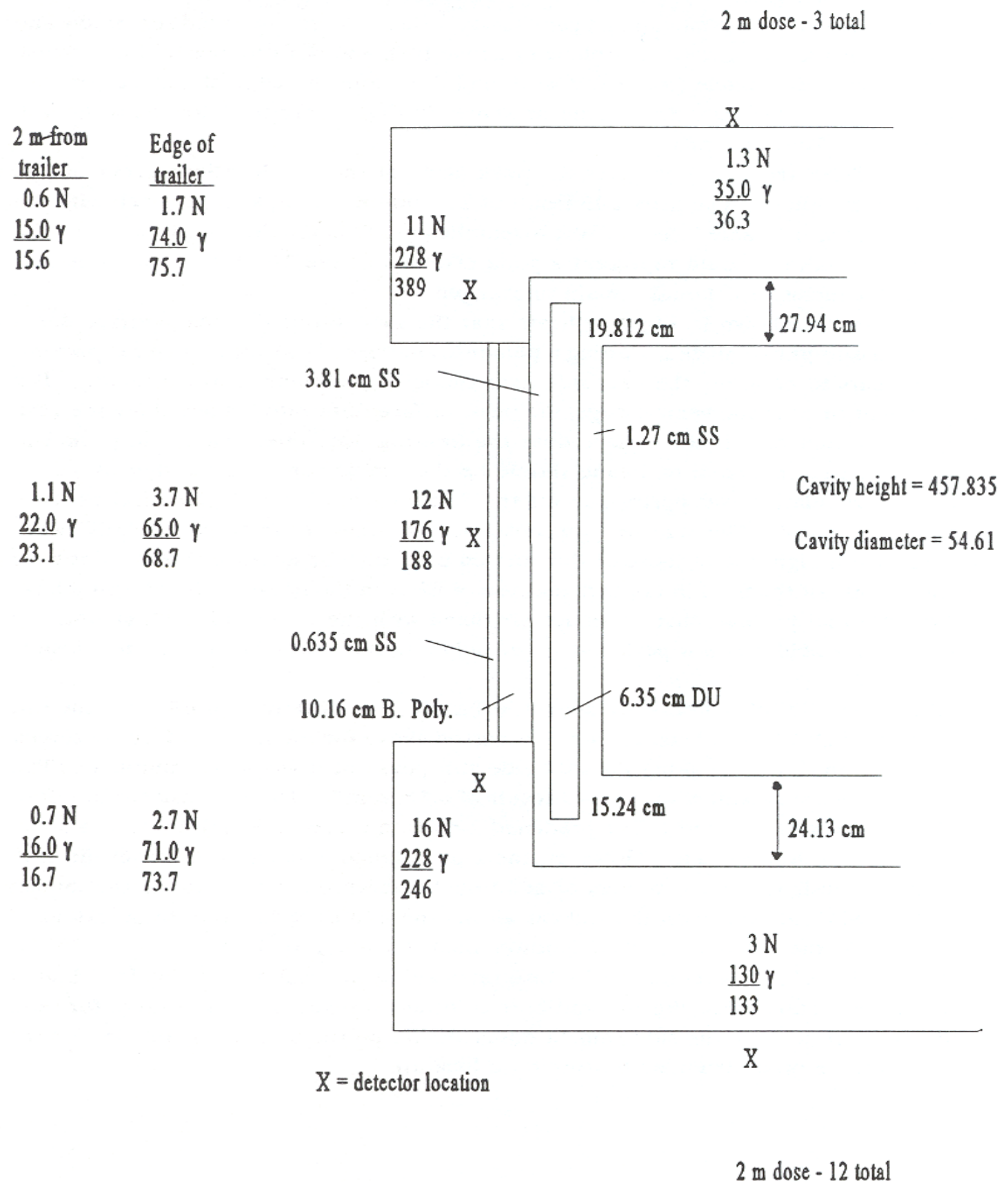

Fig. 5. Two-dimensional dose rates $(\mathrm{mrem} / \mathrm{h})$ for $2 \mathrm{PWR}$ assembly depleted uranium truck cask (40 Gwd/MTU, 5-year-cooled fuel). 


\begin{tabular}{|c|c|}
\hline $\begin{array}{l}2 \mathrm{~m} \text { from } \\
\text { railcar }\end{array}$ & $\begin{array}{l}\text { Edge of } \\
\text { railcar }\end{array}$ \\
\hline $1.4 \mathrm{~N}$ & $6.3 \mathrm{~N}$ \\
\hline $2.8 y$ & $\underline{18.8 \gamma}$ \\
\hline 4.2 & 25.1 \\
\hline
\end{tabular}

$2.3 \mathrm{~N} \quad 4.3 \mathrm{~N}$

$\underline{7.5} \gamma \quad \underline{13.1} \gamma$

$9.8 \quad 17.4$

$\begin{array}{ll}2.0 \mathrm{~N} & 11.1 \mathrm{~N} \\ \frac{4.1 \gamma}{6.1} & \underline{20.5 \gamma} \\ 31.6\end{array}$

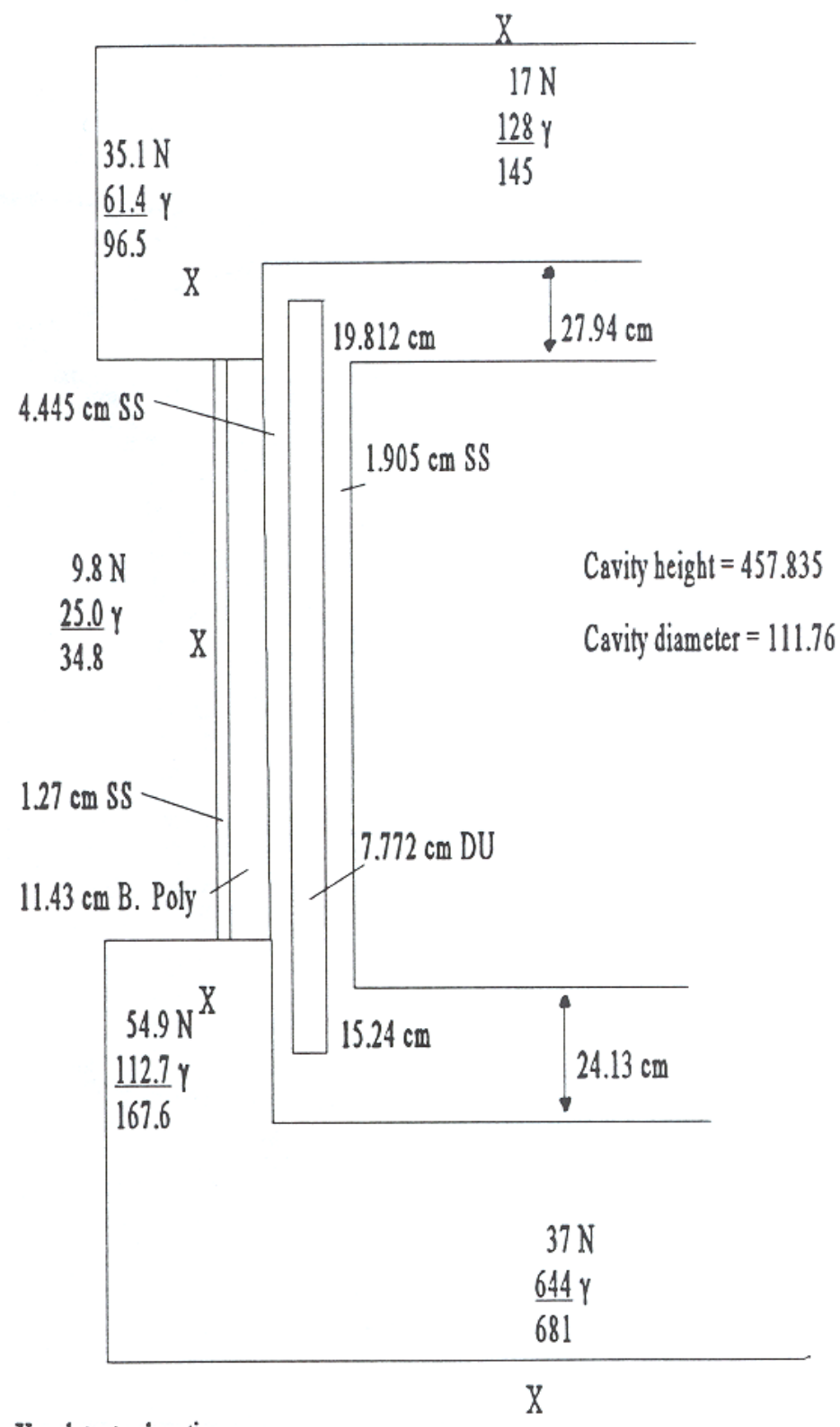

$X=$ detector location

Fig. 6. Two-dimensional dose rates (mrem/h) for $12 \mathrm{PWR}$ assembly depleted uranium rail cask (40 Gwd/MTU, 5-year-cooled fuel). 


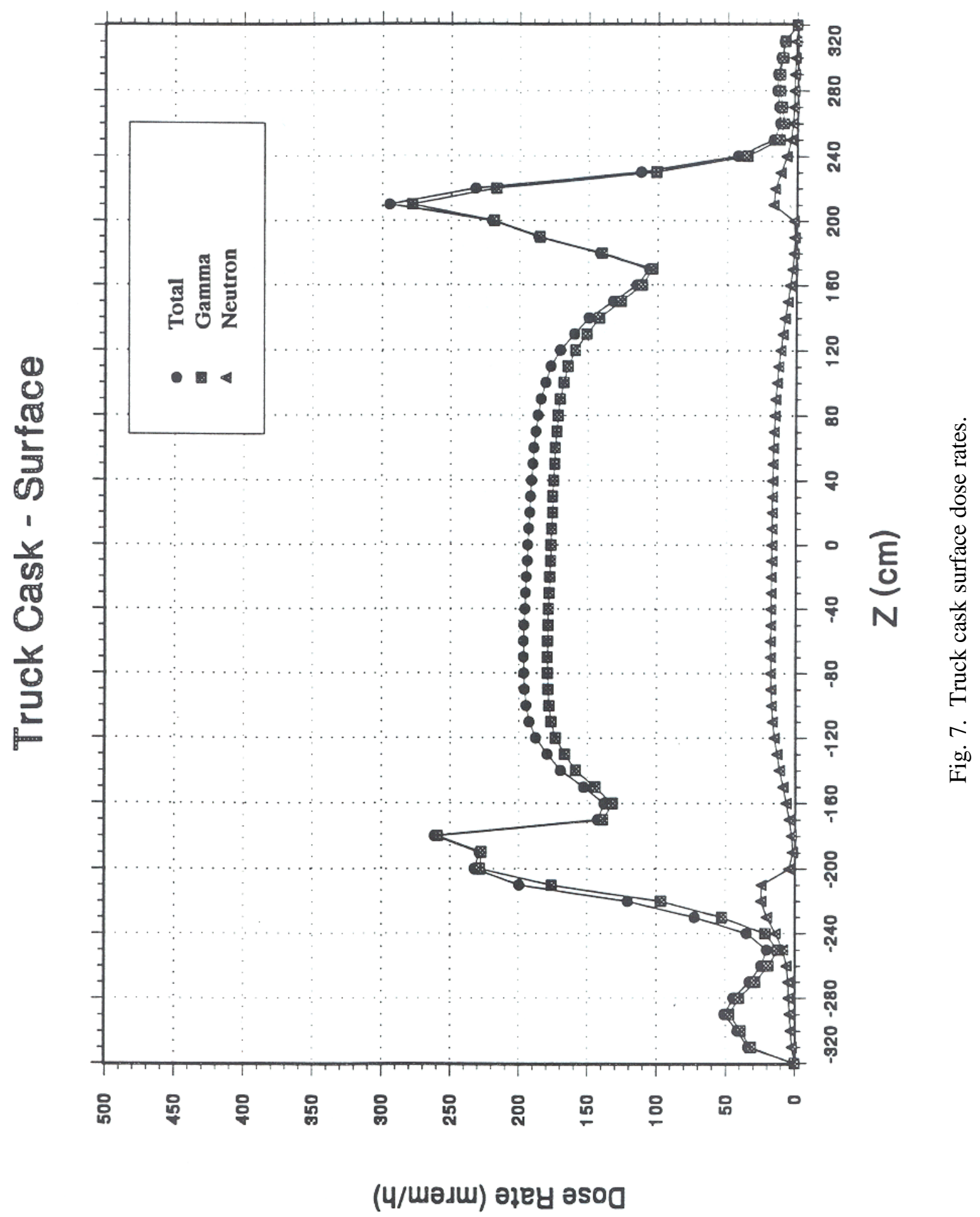




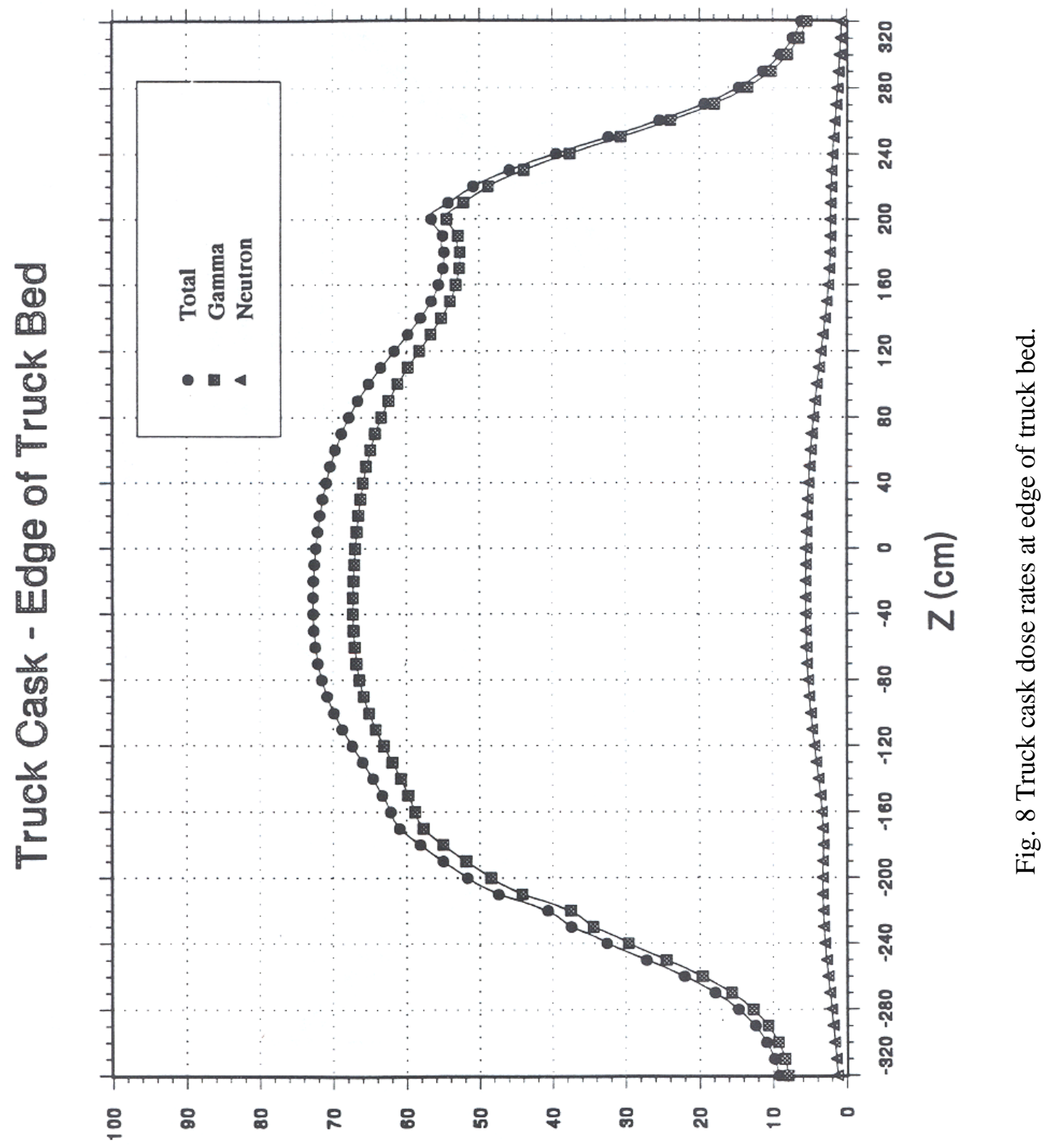

(4/щәرس) әџеप әsо0 


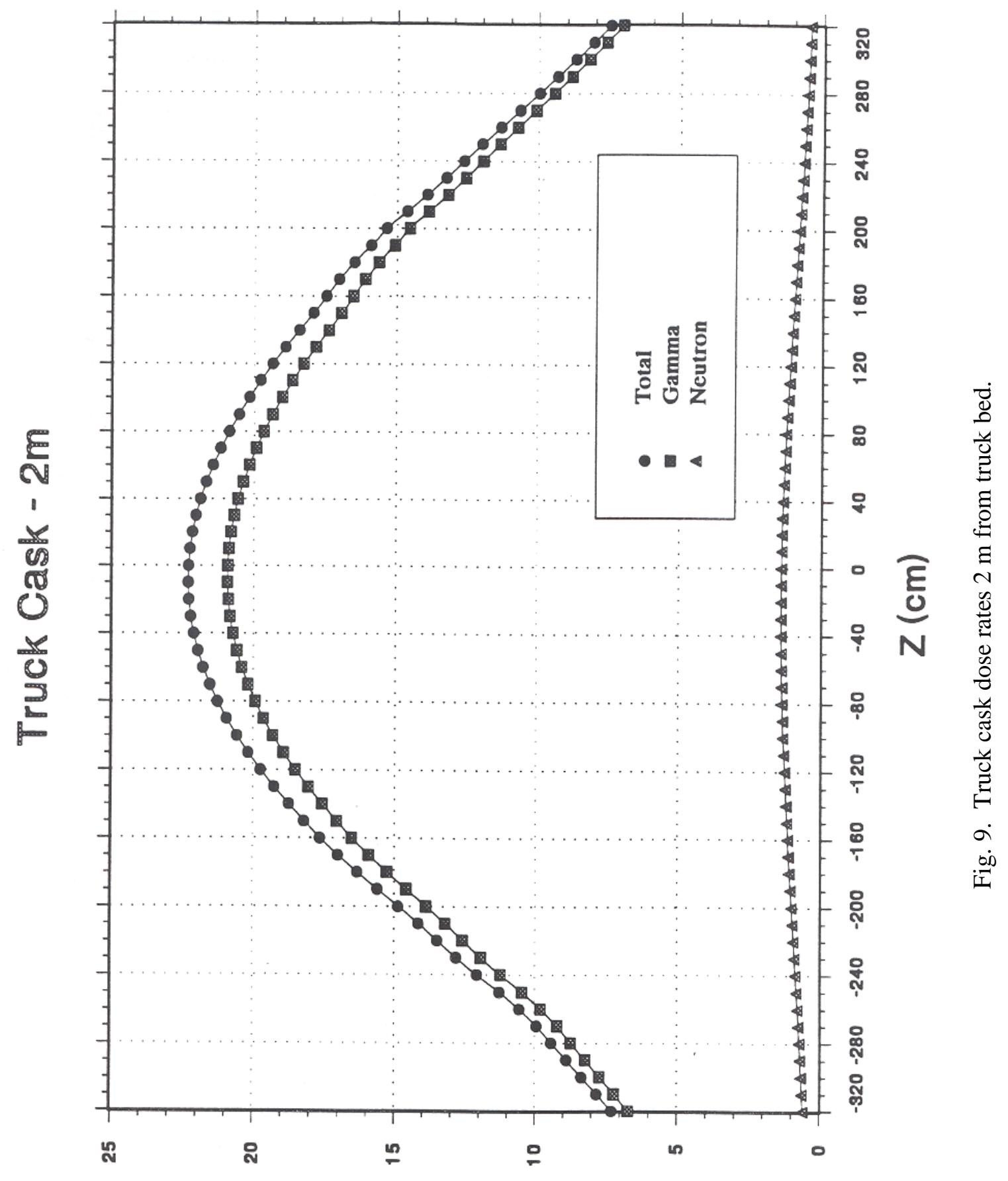

(प/سәرس) әฺеप әsо0 


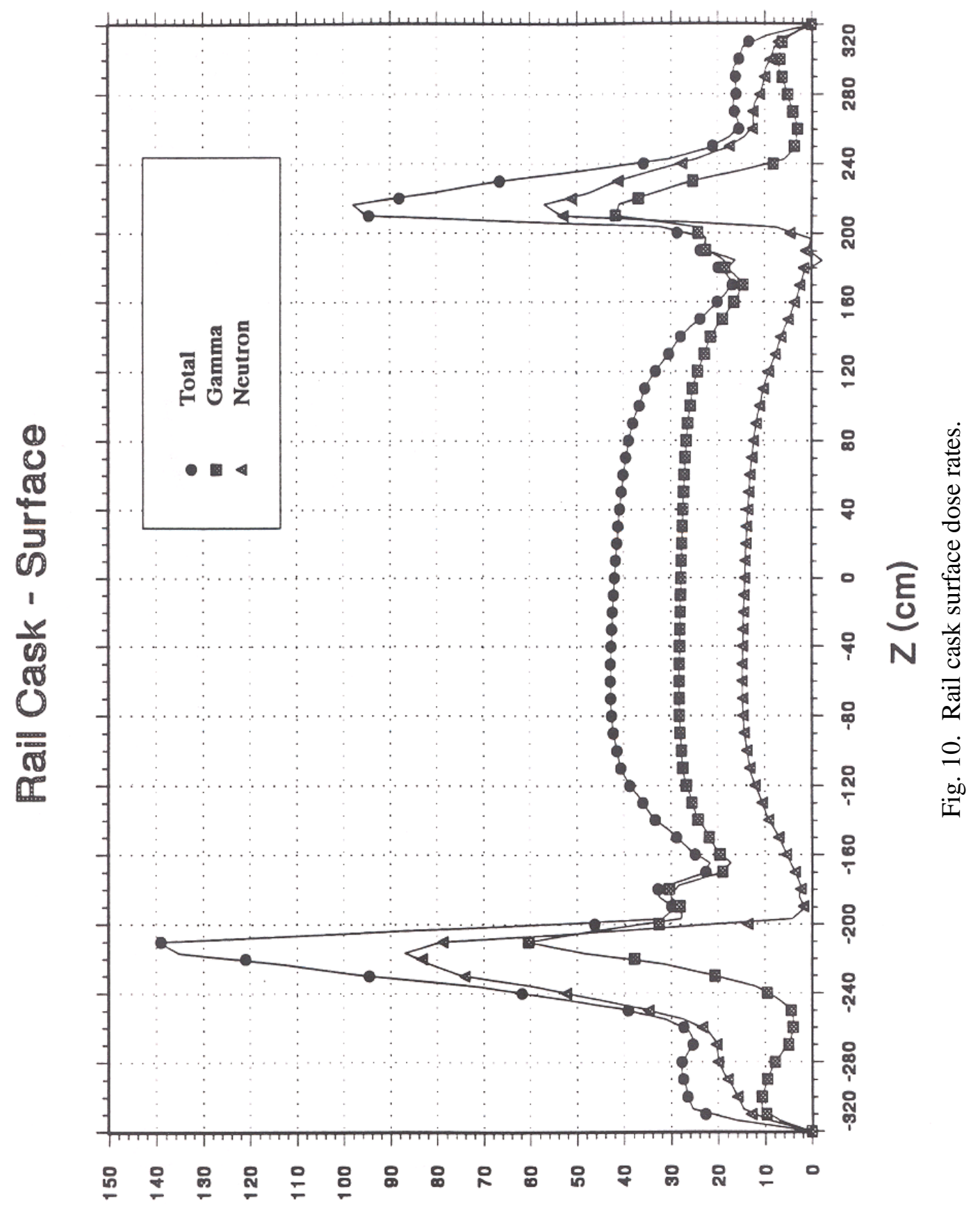

(प/سәرس) әฺеप әsog 


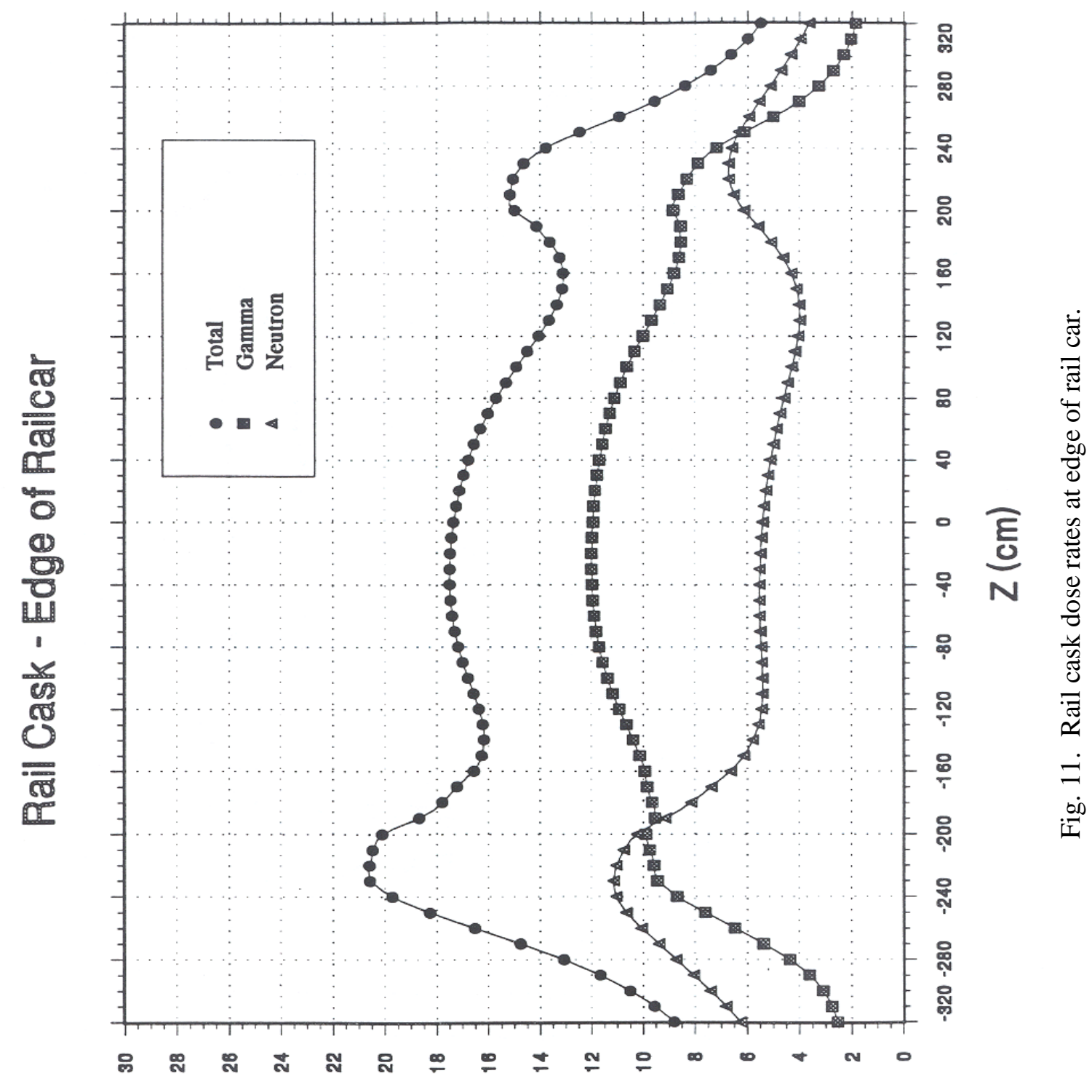

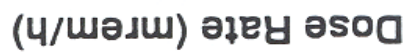




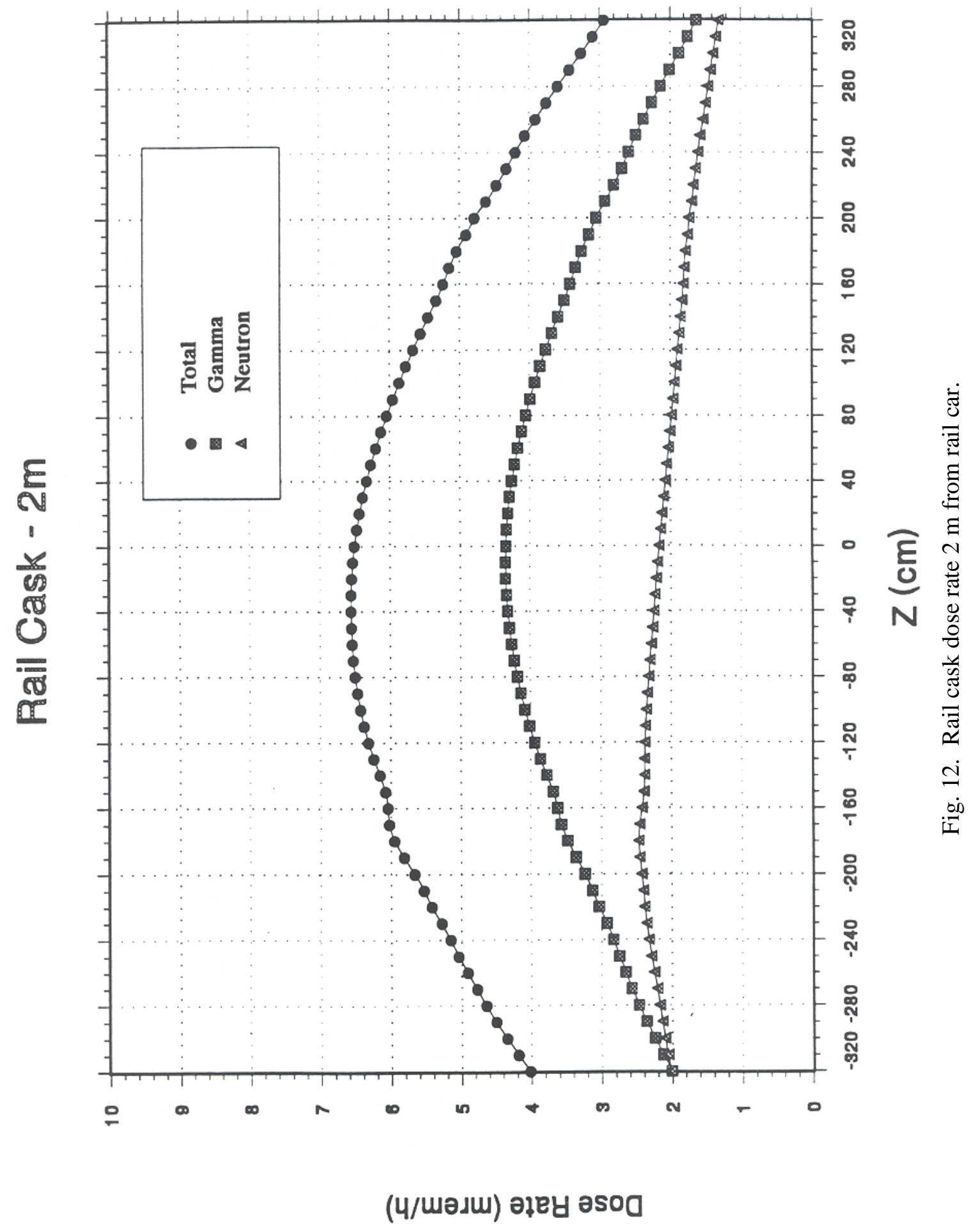




\section{CRITICALITY CALCULATIONS}

A determination of the acceptability of the TESS rail and truck casks with respect to criticality safety requirements was also desired from this study. Initial estimates based on previous work ${ }^{16}$ indicated that both casks might carry $5 \mathrm{wt} \%$ fuel with a basket web consisting of a pair of $1.27-\mathrm{cm}$ boral/steel plates separated by approximately $1.27 \mathrm{~cm}$ of water. These boral/steel plates consisted of $0.927 \mathrm{~cm}$ of SS-304 and $0.343 \mathrm{~cm}$ of boral. To confirm these estimates, KENO V.a ${ }^{7}$ models of the two casks containing $5 \mathrm{wt} \%$ fresh fuel were prepared for analysis. For the truck cask, two different PWR basket models were studied. Both models shown in Fig. 13 use the basket web consisting of $1.27-\mathrm{cm} \mathrm{boral} / \mathrm{steel}$ plates separated by $1.905 \mathrm{~cm}$ of water.

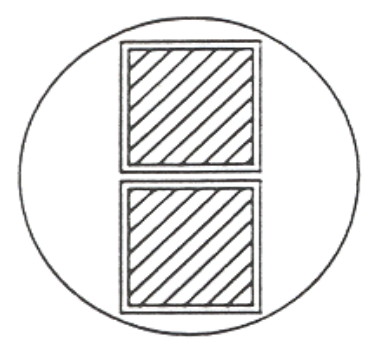

Model A

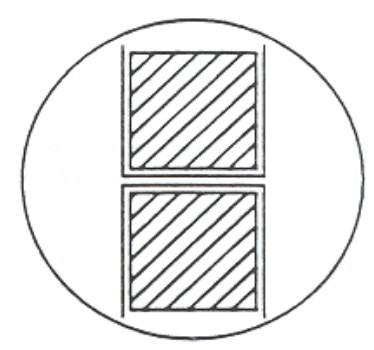

Model B

Fig. 13. Truck cask criticality models.

Four cases were analyzed for the truck cask, consisting of one case using model A and three cases for model B. The two models are similar; however, model B omits the two outermost boral/steel plates. Cases analyzed include a single cask package, an infinite array of cask packages, and an infinite array of cask packages, assuming a $25 \%$ reduction in the boron content. The truck cask results shown in Table 11 for cases 1 through 4 show that even when a typical bias of 0.01 ) k and 2 standard deviations (-0.009) are included, the $\mathrm{k}_{\text {eff }}$ value is still well below 0.95 .

In the rail cask analysis, a total of four models were used, as shown in Fig. 14, for the 10-PWR assembly basket and in Fig. 15 for the 12-PWR assembly basket. The results for the 10-assembly basket shown in Table 11 again show the sensitivity of $\mathrm{k}_{\mathrm{eff}}$ to the outer boral/steel plates. The infinite array results both with and without reduced boron concentrations indicate little effect due to the reduced boron. The 12-assembly infinite array results in general agreement within 1 standard deviation of the 10assembly infinite array results. However, after accounting for a 0.01-) $\mathrm{k}$ bias and 2 standard deviations (-0.009), these values exceed the 0.95 limit by about 3\%. Cases 9 and 10 show about a 1 to $1.5 \%$ decrease in $\mathrm{k}_{\text {eff }}$ for $4.5 \mathrm{wt} \%$ instead of $5.0 \mathrm{wt} \%$ fuel. It is estimated that a $2.54-\mathrm{cm}$ water gap would decrease $\mathrm{k}_{\text {eff }}$ about 0.03 . Thus, it is believed that a combination of decreased enrichments and/or increased water gaps should make these configurations acceptable. The 10 -assembly model D basket could easily accommodate a $2.54-\mathrm{cm}$ water gap. The 12 -assembly model F basket could accommodate a $2.54-\mathrm{cm}$ water gap but with very tight tolerances. 
Table 11. Criticality results for rail and truck casks ${ }^{\mathrm{a}}$

\begin{tabular}{clcll}
\hline $\begin{array}{c}\text { Case } \\
\text { No. }\end{array}$ & $\begin{array}{c}\text { Type cask } \\
\text { (No. } \\
\text { assemblies) }\end{array}$ & Model & \multicolumn{1}{c}{$\mathrm{k}_{\text {eff }}$} & \multicolumn{1}{c}{ Comments } \\
\hline 1 & Truck (2) & A & $0.8498 \pm 0.0045$ & Single cask \\
2 & Truck (2) & B & $0.8921 \pm 0.0044$ & Single cask \\
3 & Truck (2) & B & $0.9002 \pm 0.0043$ & Infinite array \\
4 & Truck (2) & B & $0.9056 \pm 0.0048$ & Infinite array, 75\% boron \\
& & & & \\
5 & Rail (10) & C & $0.9491 \pm 0.0042$ & Single cask \\
6 & Rail (10) & D & $0.9872 \pm 0.0045$ & Single cask \\
7 & Rail (10) & C & $0.9586 \pm 0.0044$ & Infinite array \\
8 & Rail (10) & C & $0.9572 \pm 0.0046$ & Infinite array, 75\% boron \\
& & & & \\
9 & Rail (12) & E & $1.0157 \pm 0.0042$ & Single cask \\
10 & Rail (12) & E & $1.0001 \pm 0.0045$ & Single cask, 4.5\% enrichment \\
11 & Rail (12) & F & $0.9541 \pm 0.0046$ & Single cask \\
12 & Rail (12) & F & $0.9600 \pm 0.0044$ & Infinite array \\
\hline
\end{tabular}

${ }^{\mathrm{a}}$ All enrichments were $5.0 \mathrm{wt} \%$ unless otherwise noted.
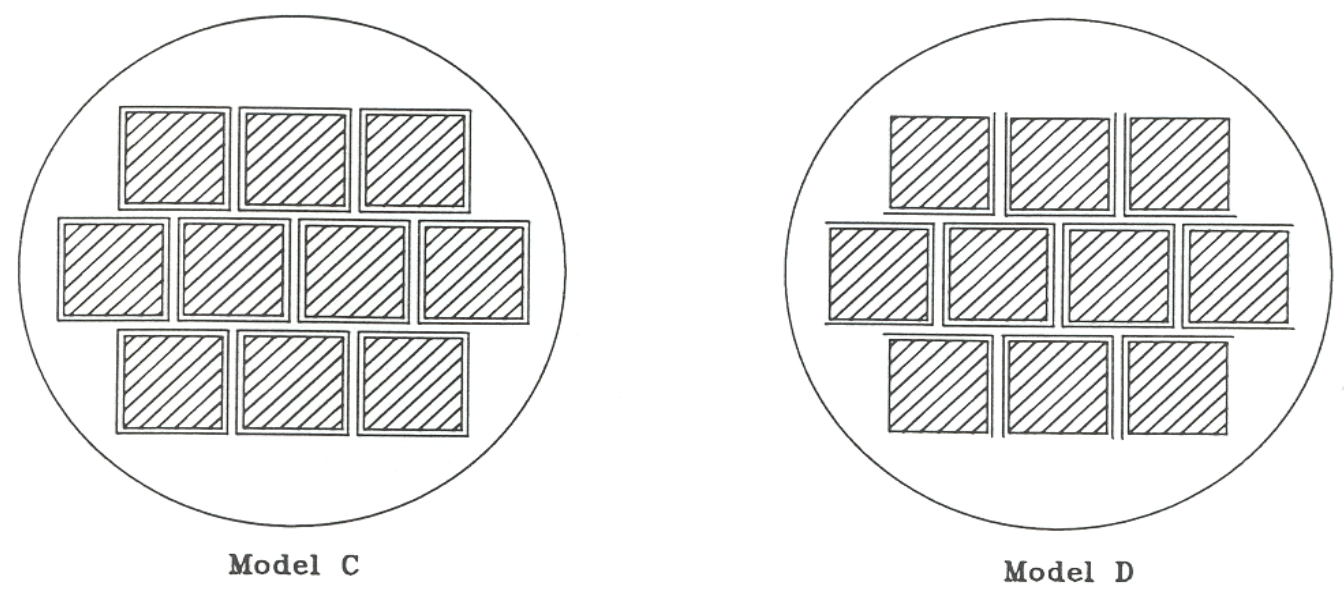

Fig. 14. Rail cask model containing 10 PWR assemblies. 

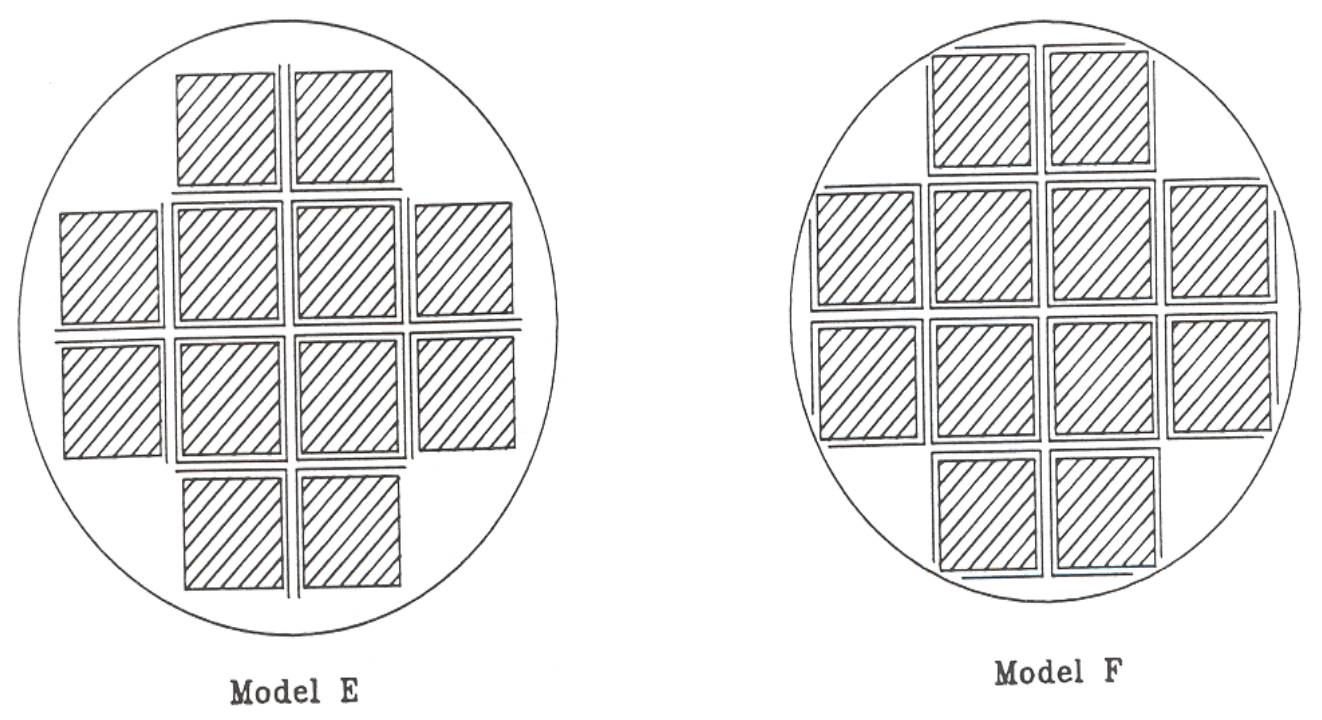

Fig. 15. Rail cask model containing 12 PWR assemblies. 


\section{SUMMARY}

This work has analyzed in one and/or two dimensions the adequacy with respect to shielding regulations of reference designs for a truck cask containing 2 PWR or 5 BWR assemblies of standard burnup (45 GWd/MTU for PWR, $40 \mathrm{GWd} / \mathrm{MTU}$ for BWR) and 1 PWR assembly with extended burnup (55 GWd/MTU). The study also included a reference and modified rail cask design with projected payloads of 8,10 , or 12 PWR assemblies. The burnup/age trends were analyzed in one dimension for both $\mathrm{Pb}$ and DU gamma-ray shields. The 2-D analyses concentrated on multidimensional aspects of each design and the degree to which the 1-D results were adequate. Finally, both cask types were analyzed for adequacy from a criticality safety standpoint.

The results of the 1-D shielding analysis are summarized in Figs. 16 and 17 for the reference truck casks. The 2-D truck cask analysis upheld the 1-D results as being an appropriate means of studying the burnup/age trends for the truck cask. These curves show that the reference design for the $\mathrm{Pb}$-shield truck cask is inadequate, while the DU-shield truck cask is capable of carrying the desired payloads.

The 1-D shielding analysis results for the reference $\mathrm{Pb}$ and DU rail casks are shown in Figs. 18 and 19. For the DU cask, there are substantial margins in the side doses for reasonable burnup/age combinations. For a Pb-cask configuration, margins exist primarily for long-cooled (15 years) fuel.

For the modified $\mathrm{Pb}$ and DU rail cask results shown in Figs. 20 and 21, the 2-m dose rate offers substantial margins below the regulatory limits for practically all burnup/age combinations. $\mathrm{The} \mathrm{Pb}$ and DU casks yield essentially identical results and, hence, could be considered equivalent from a shielding perspective.

An acceptable margin for the sake of these comparisons is believed to be a $25 \%$ reduction from the regulatory limit, or a target $2-\mathrm{m}$ total dose rate limit of $7.5 \mathrm{mrem} / \mathrm{h}$. This margin includes the low enrichment effect, which was shown to be about $15 \%$ of the total dose. It also takes into account various effects that were discussed throughout the report, primarily azimuthal variations, endfitting effects, 1-D versus 2-D, the axial burnup profile, and groundscatter effects. For all but the groundscatter effects, the 1 -D representations appear to be accurate or produce conservative results at the $2-\mathrm{m}$ location. The groundscatter effects are estimated to be 10 to $15 \%$ of the total dose, with the lower value chosen because the remaining effects were believed to yield conservative results.

The criticality analyses that were performed indicate that a truck basket can be designed to provide an adequate subcritical margin for 2 PWR assemblies enriched to $5 \mathrm{wt} \%$. While the 10 - and 12assembly rail cask designs are very close to the limit of 0.95 for $\mathrm{k}_{\mathrm{eff}}$, after accounting for a 0.01 ) $\mathrm{k}$ bias and 2 standard deviations, the limit is exceeded by about 3\%. It is believed that a combination of decreased enrichments and/or increased water gaps should allow these baskets to be acceptable. 


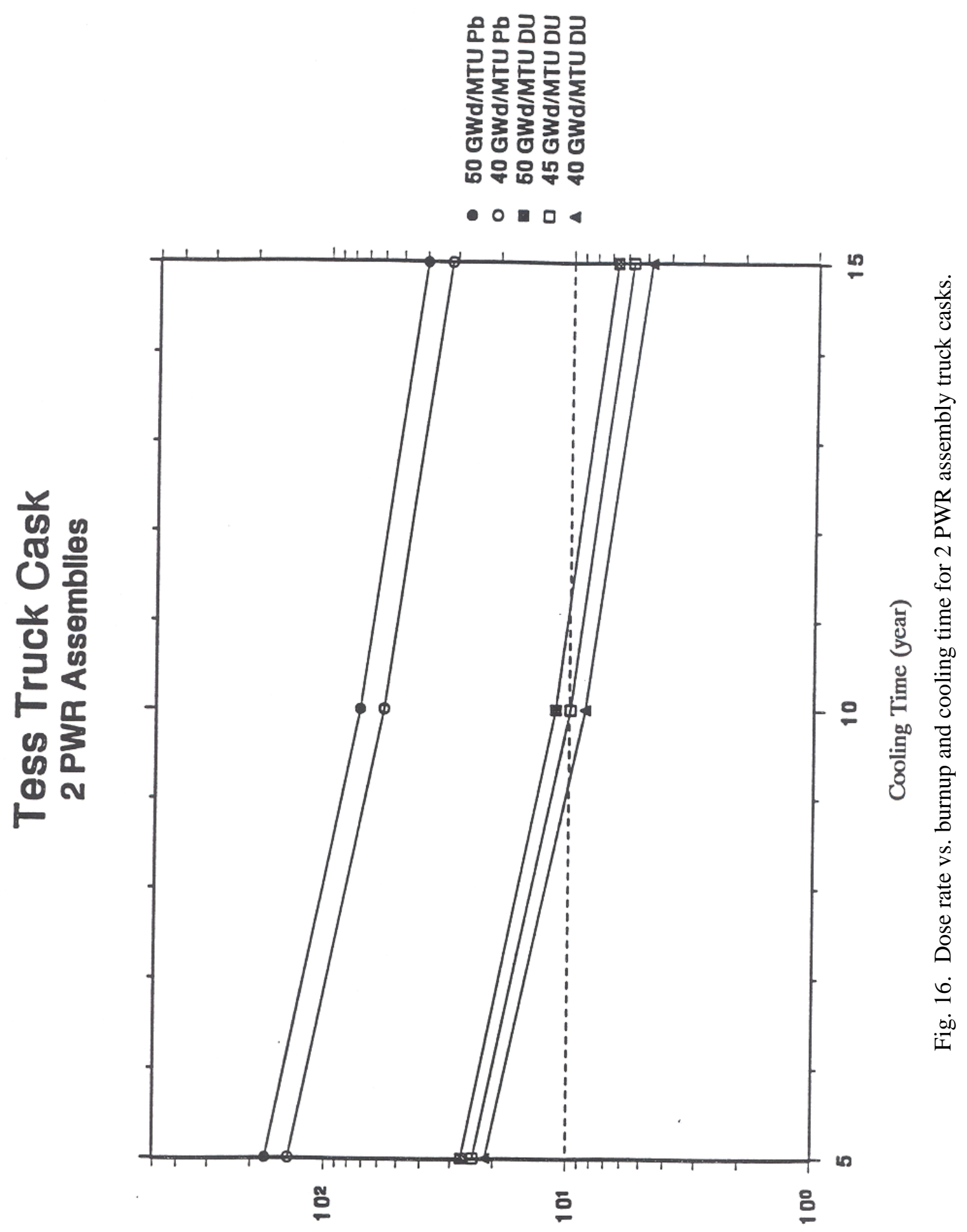

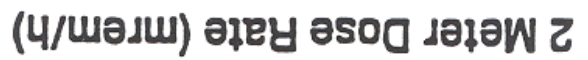




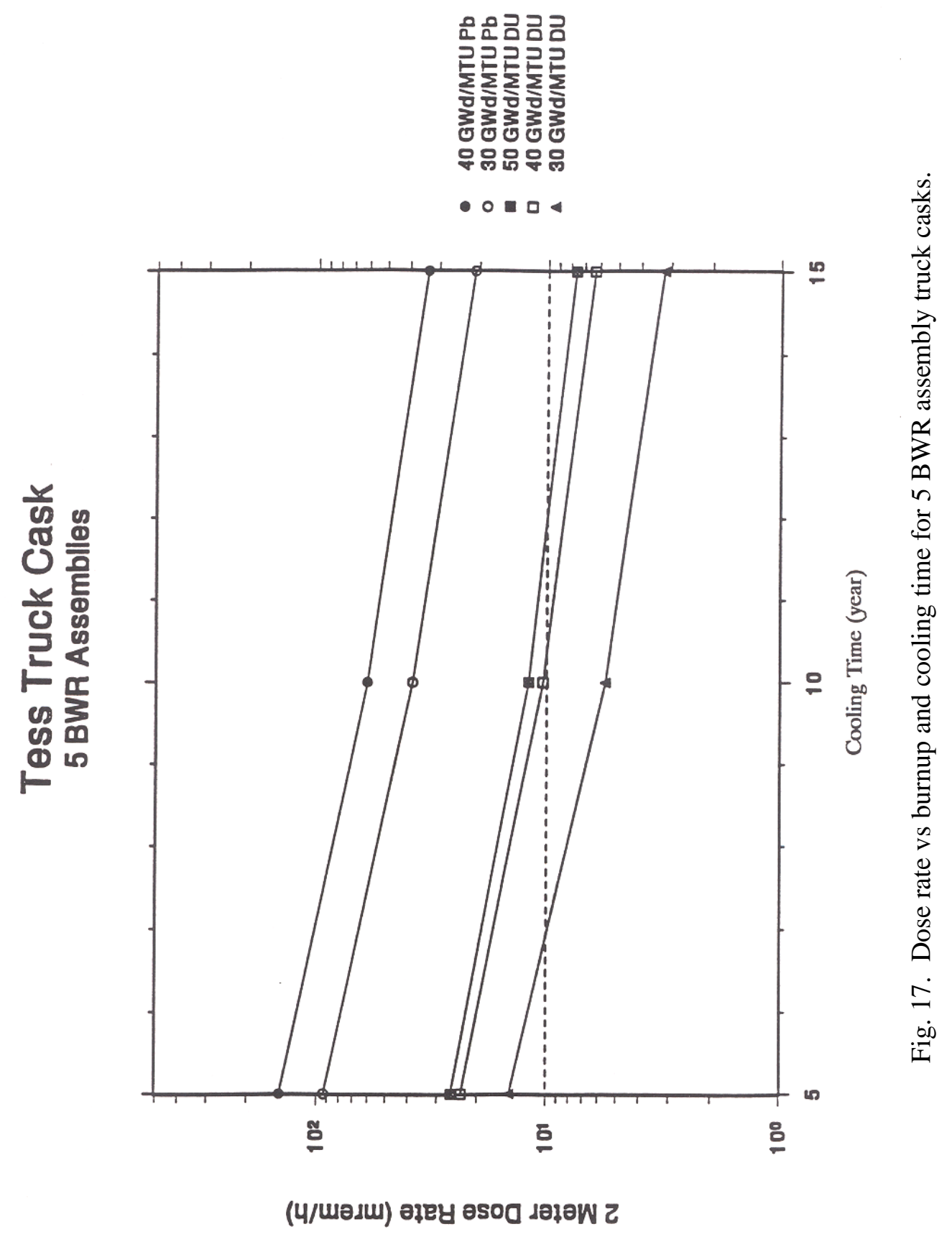



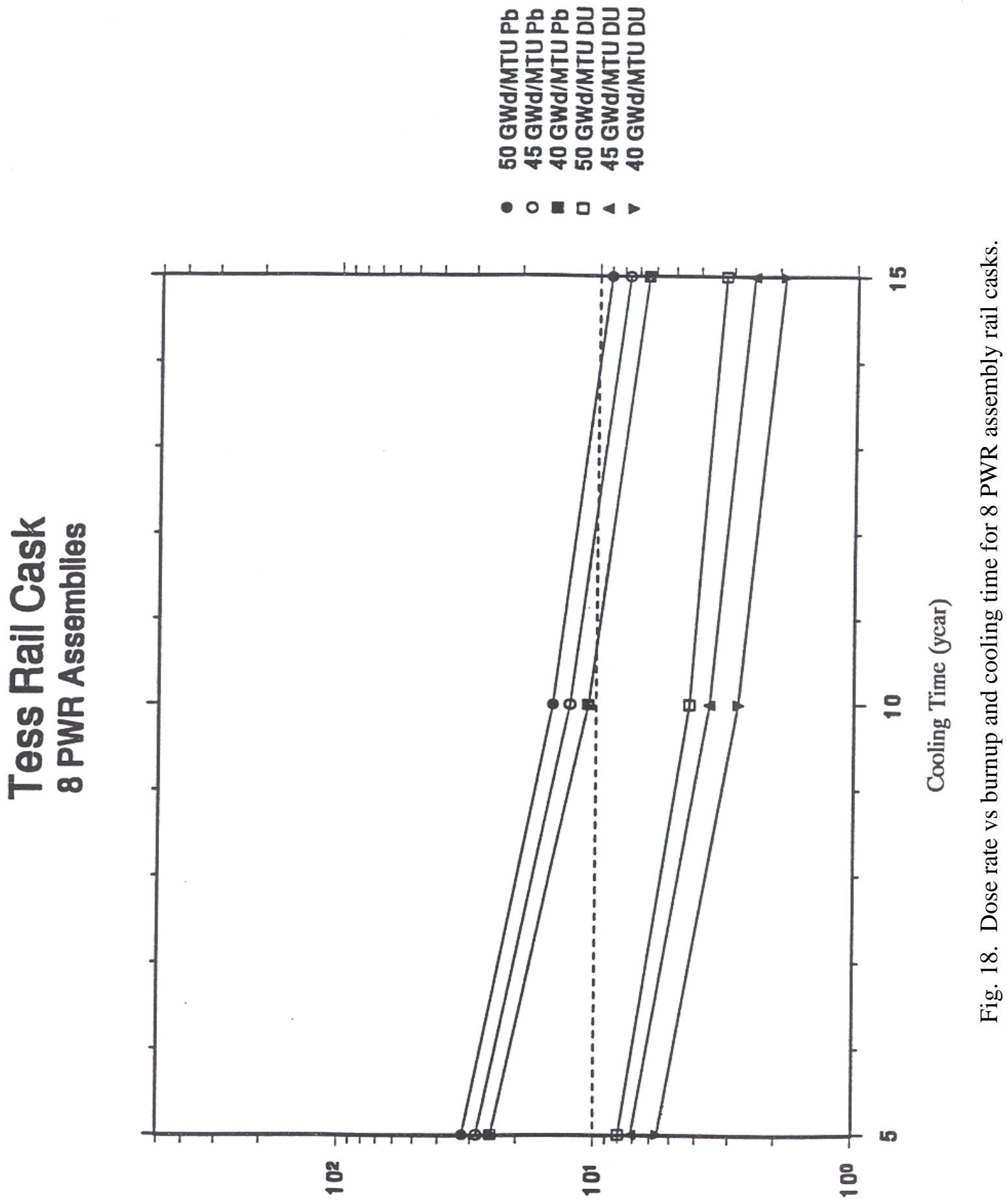

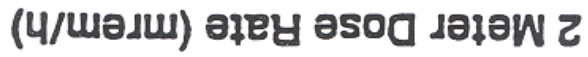




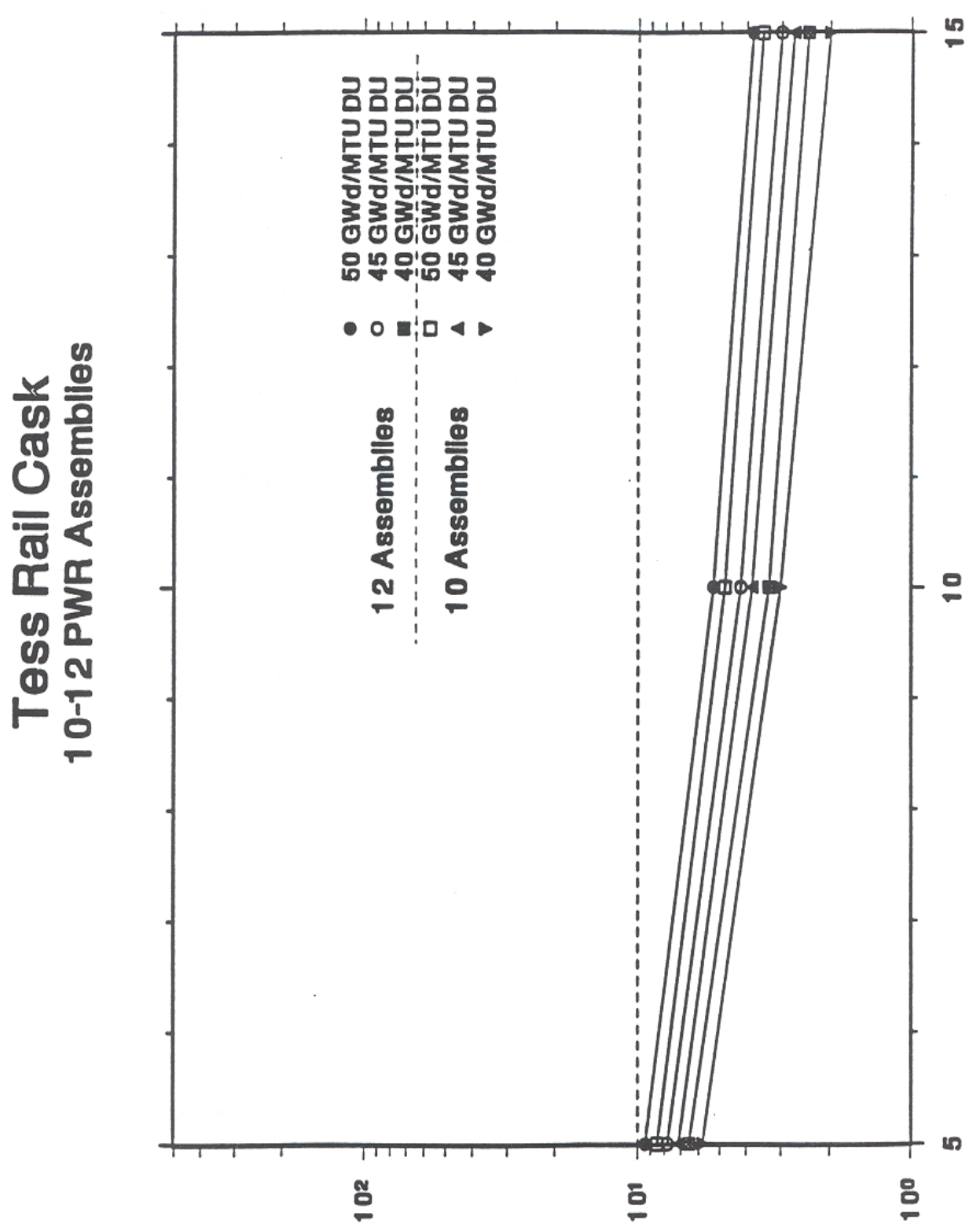

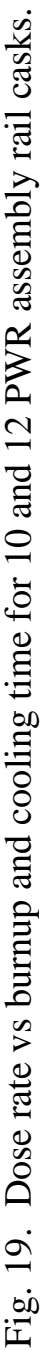

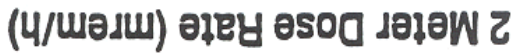




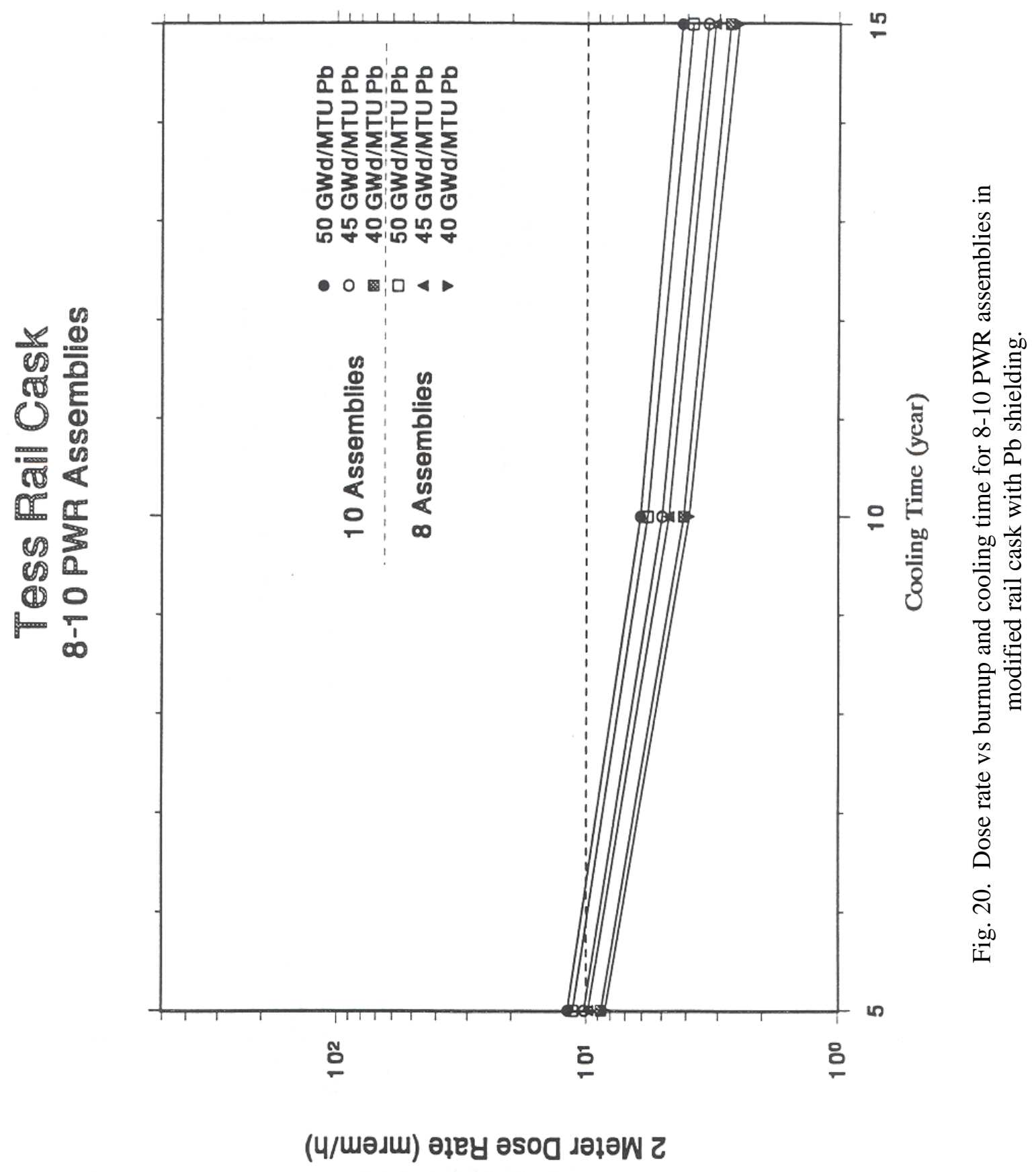




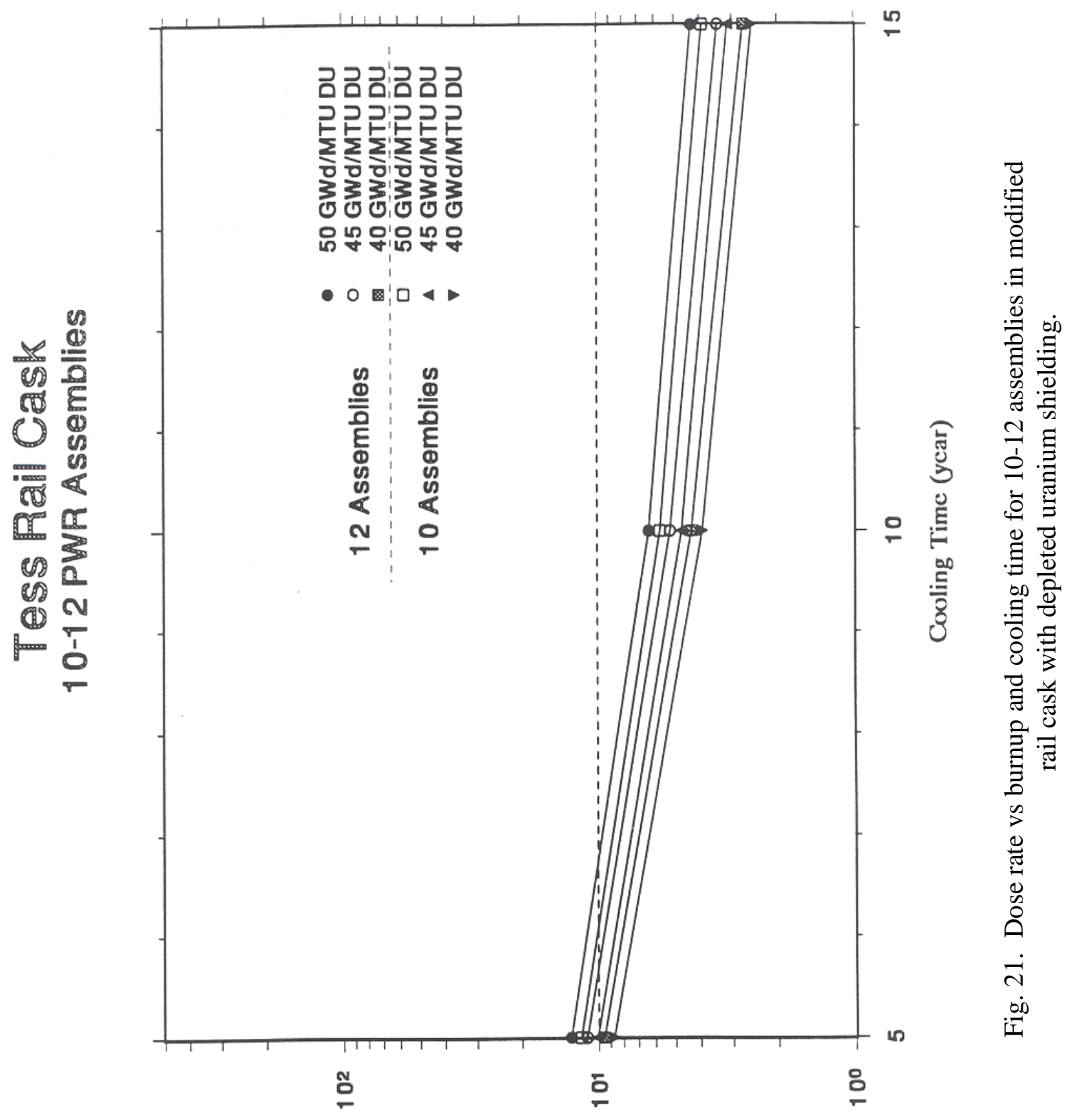

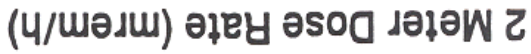




\section{REFERENCES}

1. C. V. Parks et al., Assessment of Shielding Analysis Methods, Codes, and Data for Spent Fuel Transport/Storage Applications," ORNL/CSD/TM-246, Martin Marietta Energy Systems, Inc., Oak Ridge Natl. Lab., July 1988.

2. B. L. Broadhead, M. C. Brady, and C. V. Parks, Benchmark Shielding Calculations for the NEACRP Working Group on Shielding Assessment of Transportation Packages ORNL/CSD/TM-272, Martin Marietta Energy Systems, Inc., Oak Ridge Natl. Lab., November 1990.

3. Nuclear Energy Agency of the OECD, Standard Problem Exercise on Criticality Codes for Spent LWR Fuel Transport Containers, CSNI Rep. No. 71, Organization for Economic Cooperation and Development/Nuclear Energy Agency, Paris, 1982.

4. Nuclear Energy Agency of the OECD, Standard Problem Exercise on Criticality Codes for Large Arrays of Fissile Materials, CSNI Rep. No. 78, Organization for Economic Cooperation and Development/Nuclear Energy Agency, Paris, 1982.

5. W. C. Jordan, N. F. Landers, and L. M. Petrie, Validation of KENO V.a Comparison with Critical Experiments, ORNL/CSD/TM-238, Martin Marietta Energy Systems, Inc., Oak Ridge Natl. Lab., December 1986.

6. Packaging and Transportation of Radioactive Material, Part 71, Code of Federal Regulations, Revised as of January 1, 1992.

7. SCALE: A Modular Code System for Performing Standardized Computer Analyses for Licensing Evaluation, NUREG/CR-0200, Rev. 4 (ORNL/NUREG/CSD-2/R4), Vols. I, II, and III (draft February 1990). Available from Radiation Shielding Information Center, Oak Ridge National Laboratory, as CCC-545.

8. ANSI/ANS-6.1.1-1977, Neutron and Gamma-Ray Flux-to-Dose-Rate FactorsAmerican Nuclear Society (1977).

9. GA-4/GA-9 Legal Weight Truck From Reactor Spent Fuel Casks - 70\% Design Review Package, DOE Contract DE-AC07-88ID12698 (November 1990).

10. Safety Analysis Report for the NAC Legal Weight Truck Cask, NRC Docket \#71-9225, Rev. 6, July 1990.

11. Characteristics of Potential Repository Waste@OE/RW-0184-R1, Vols. 1-4, U.S. Department of Energy, Washington, D.C., July 1992.

12. J. W. Roddy et al., Physical and Decay Characteristics of Commercial LWR Spent Fuel , ORNL/TM-9591/V1, Martin Marietta Energy Systems, Inc., Oak Ridge Natl. Lab., October 1985. 
13. W. A. Rhoades and R. L. Childs, Two- and Three-Dimensional Discrete Ordinates Transport, January 1992. Available from Radiation Shielding Information Center, Oak Ridge National Laboratory, as CCC-543/TORT-DORT; see also W. A. Rhoades and R. L. Childs, An Updated Version of the DOT 4 One- and Two-Dimensional Neutron/Photon Transport Code, ORNL5851, Union Carbide Corp., Nucl. Div., Oak Ridge Natl. Lab., July 1982.

14. The TN-24P PWR Spent-Fuel Storage Cask: Testing and Analyses, EPRI NP-5128, Electric Power Research Institute, Palo Alto, California, April 1987.

15. B. H. Wakeman, S. A. Ahmed, and M. L. Smith, "Evaluation of Burnup Credit for Dry Storage Casks," Proceedings of a Workshop on the Use of Burnup Credit in Spent Fuel Transport Casks, SAND89-0018 (TTC-0884), Sandia National Laboratories, Albuquerque, New Mexico, October 1989.

16. R. M. Westfall, "Effects of Burnup Credit on Cask Basket Design Spacing Requirements," Proceedings of a Workshop on the Use of Burnup Credit in Spent Fuel Transport Casks , SAND89-0018 (TTC-0884), Sandia National Laboratories, Albuquerque, New Mexico, October 1989.

17. B. L. Broadhead, C. V. Parks, and R. B. Pope, "Assessment of Proposed Dose Factor Changes to Shipping Cask Design and Operation," Proceedings of 1992 International High-Level Radioactive Waste Management Conference, Las Vegas, Nevada, April 12-16, 1992. 

ORNL/TM-12395

\section{INTERNAL DISTRIBUTION}

1. S. M. Bowman

2-3. B. L. Broadhead

4-5. R. L. Childs

6. M. D. DeHart

7. M. B. Emmett

8. N. M. Greene

9. O. W. Hermann

10. M. A. Kuliasha

11. L. F. Norris

12-13. C. V. Parks

14. L. M. Petrie
15. R. B. Pope

16. C. H. Shappert

17. J. S. Tang

18. R. M. Westfall

19-20. Laboratory Records Dept.

21. Laboratory Records, ORNL-RC

22. ORNL-y-12 Technical Library

23. Central Research Library

Document Reference Section

24. ORNL Patent Section

\section{EXTERNAL DISTRIBUTION}

25. J. R. Clark, TRW Environmental Safety Systems, 2650 Park Tower Drive, Vienna, VA 22180

26. T. W. Doering, TESS, B\&W Fuel Co., MS 423, Suite 527, P.O. Box 98608, 101 Convention Center Drive, Las Vegas, NV 89109

27. W. H. Lake, Office of Civilian Radioactive Waste Management, U.S. Department of Energy, RW-33, Washington, DC 20545

28. N. B. McLeod, E. R. Johnson Associates, 10461 White Granite Drive, Oakton, VA 22124

29. Office of the ORNL Site Manager,Department of Energy, Oak Ridge Operations, P.O. Box 2008, Oak Ridge, TN 37831

30-31. Office of Scientific and Technical Information, P.O. Box 62, Oak Ridge, TN 37831

32. O. Ozer, Electric Power Research Institute, 3412 Hillview Ave., Palo Alto, CA 94304

B. R. Teer, TRW Environmental Safety Systems, 2650 Park Tower Drive, Vienna, VA

33. 22180 